This PDF is a simplified version of the original article published in Internet Archaeology. Enlarged images and data which support this publication can be found in the original version online. All links also go to the online version.

Please cite this as: Heen-Pettersen, A.M. 2021 Evidence of Viking trade and 'Danelaw' connections? Inset lead weights from Norway and the western Viking World, Internet Archaeology 56.

https://doi.org/10.11141/ia.56.10

\title{
Evidence of Viking trade and 'Danelaw' connections? Inset lead weights from Norway and the western Viking World
}

\author{
Aina Margrethe Heen-Pettersen
}

\section{Summary}

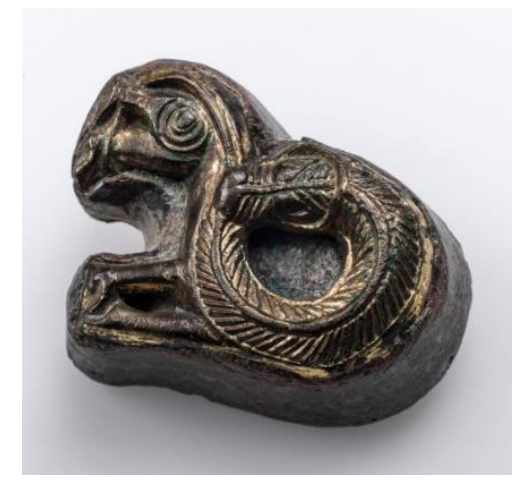

Weight with a gilded bronze mount in the form of a four-footed animal with a snake-like body and a long neck (T18198d)

This article presents and discusses the use and itineraries of inset lead weights from Norway and the wider Viking world. The weights, which are mostly inset with decorated metalwork, coins and glass are likely to be of 'Insular-Viking' manufacture, which developed in the late 9th and/or early 10th century. While the Norwegian corpus has generally received attention for its 'Irish' style of metalwork and therefore Irish affiliation, this article demonstrates how some of the material may rather have travelled to Norway via England. Here, they were extensively used in Viking milieus and the Irish-style insets were probably carried eastwards from Ireland by some of the historically attested groups who joined the Viking armies in England. The alternative route suggested for the weights which ended up in Norway has several implications, especially for providing potential evidence for integrated contact between the Danelaw area and Norway.

The article also investigates fragmented mounts, a material phenomenon found in Viking and Norse contexts on both sides of the North Sea. While these mounts are often regarded as one group, the article identifies different practices in the fragmentation of 
this material, based on morphological details. It is suggested that 're-fashioned' pieces, i.e. those carefully cut into pieces and reworked into dress ornaments can be separated from 'hack-bronze' - those that appear to have been fragmented in the same manner as hack silver and other metals intended for reuse as scrap or as bullion.

\section{Introduction}

The extensive Scandinavian contact with Britain and Ireland (the 'Insular area' referred to in this article) during the Viking Age has been subject to intensive historical and archaeological studies for more than a century. In recent years, special attention has been devoted to the altered material culture which emerged as a result of these interactions (Glørstad 2012; 2014; Aannestad 2015; 2018). This article considers one such group of artefacts: lead weights decorated with different types of Insular copperalloy metalwork and coins. While the term 'inset weights' is used here for this material, the group also includes examples where metalwork was used as 'containers', i.e. filled with lead. Providing evidence for bullion (weight-based) exchange in a range of economic and social transactions (Pedersen 2008; Sheehan 2013) and tools for metalworking (Pedersen 2001), such weights are generally believed to have been used for weighing metals, a suggestion supported by the fact that in some burials they are found accompanied by balances.

While finds of decorated lead weights have long been recognised, the surge in metaldetecting over the last decade has led to a significant increase in the number of known examples, especially from western Scandinavia and England. This calls for a renewed investigation into the circulation and use of these artefacts. This article will focus on the inset weights from Norway and consider how they can be interpreted against the finds from the wider Viking world. It will examine the use of these lead weights, their historical context, and consider what mechanisms brought the material to western Scandinavia.

The article will also investigate how the custom of using copper-alloy metalwork as decoration on these weights relates to the wider consumption of Insular metalwork in the Viking milieu, with a particular focus on fragmented mounts. Can morphological details of fragmented Insular metalwork reveal chronological and geographical differences in the use of this material?

\section{Inset lead weights: the Norwegian material}

The Norwegian material consists of a total of 33 weights (Figure 1) which are all curated by the five archaeological museums in Norway: Museum of Archaeology, University of Stavanger (AMS); University Museum of Bergen (UiB); University of Tromsø (UiT); NTNU University museum (VM) and Museum of Cultural History (KHM). There are some 25 decorative weights and four plain examples of complete or fragmented copper-alloy Insular metalwork, as well as two weights with coins and two with glass inlay. The items were either reused as weights (one example) or, more commonly, made into settings for 
lead weights (32 examples). The insets are usually applied directly on top of the weights, either pressed into the lead itself when still fluid or fastened with small pins. In one case (from Kaupang, see below) the mount was used as a 'container' that was filled with lead to become a weight. While this article will not discuss the metrological aspects of this material, it may be noted that the weights of the well-preserved Norwegian examples vary from 4.9g to 194.7g (Table 1; Pedersen 2008, 170-3; for a discussion of weights from Yorkshire, see Kershaw 2020, 120-3).

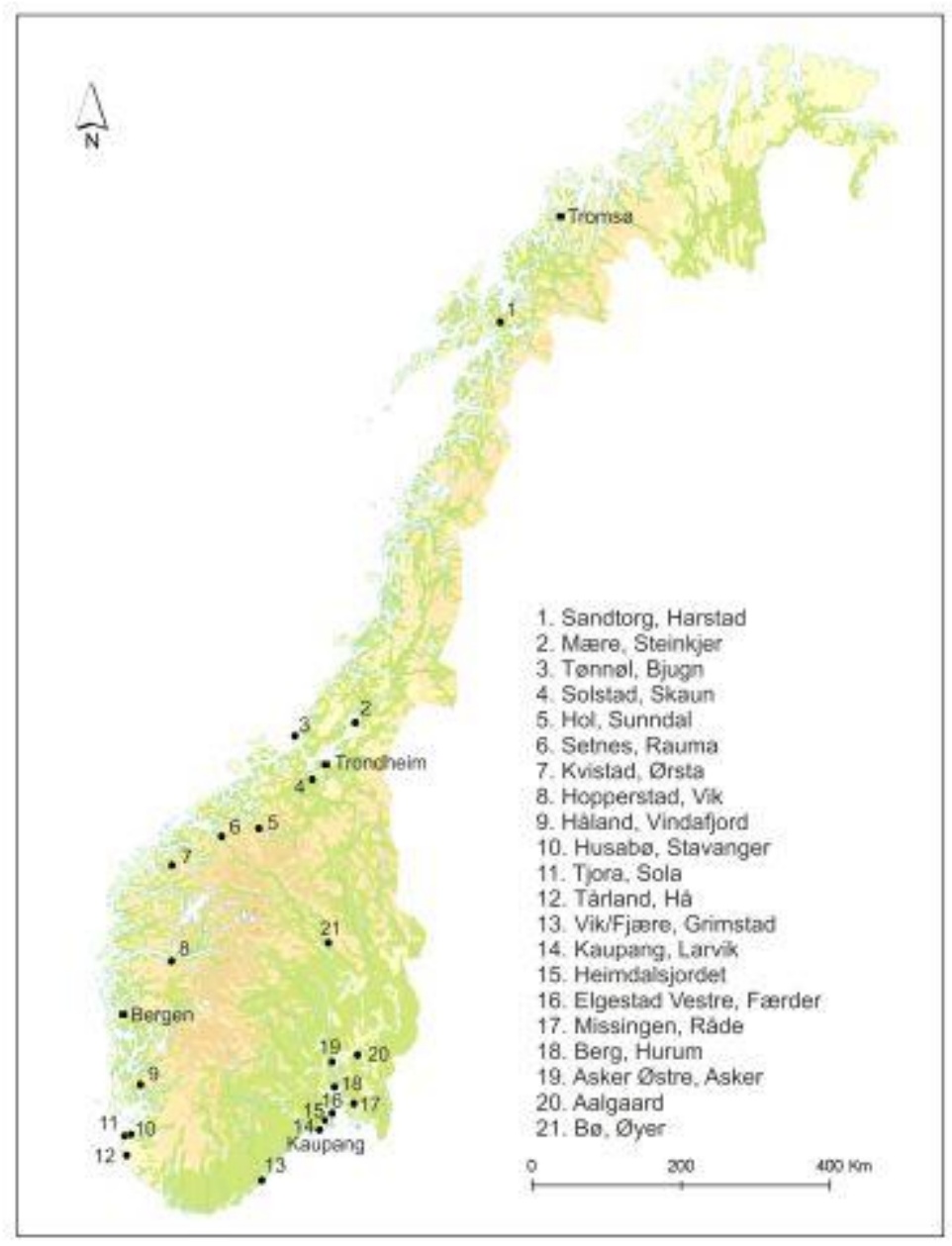

Figure 1: Distribution map of inset weights from Norway (Map by Aina Heen-Pettersen)

In terms of the contexts in which they were found, eight weights were recovered from within the settlement area of the urban site of Kaupang, Skiringssal (Pedersen 2008), while 11 examples are either stray finds or metal-detecting finds. Nine of these were recovered in the period between 2010 and 2019. A total of 14 inset lead weights derive from eight burials; two female (Setnes and Hopperstad) and four male (Tønnøl, Kvistad, Håland and Vik), while the gender association for two examples from Berg and Asker $\varnothing$ stre cannot be determined. The latter find is a previously unpublished example, discovered in 1979 as a result of metal-detecting but only recently reported to the Museum of Cultural History. It was extracted from a barrow, along with 10 other (plain) lead weights, a silver fragment and a balance scale (information from accession catalogue). While these finds may be associated, their relationship must be regarded with some caution since the finds were not recovered during controlled, professional excavation. 
In terms of dating, three burials (Håland, Setnes and Tønnøl) with inset weights were accompanied by grave goods traditionally dated to the first half of the 10th century. The Kvistad burial may only be assigned a broad 9th-century date and the Hopperstad burial has been dated to both the 9th and first half of the 10th century by different researchers (see Sørheim 2011, 41-2 for a summary discussion). However, as discussed below, the suggestion here is that both of these should probably be assigned a late 9th-century date at the earliest, based on the datable examples of inset lead weights from Britain and Ireland. The same applies to the burials from Asker Østre, Berg and Vik. None of the inset weights from Kaupang belongs to a precisely dated context and while the settlement was founded around AD 800, extensive ploughing has destroyed the settlement deposits from the latest phases. Finds recovered do indicate 'some activity as late as AD 960/980', and intense activity until around AD 930 (Pedersen and Pilø 2007; Pilø and Skre 2011, 26).

In terms of their form, the inset lead weights are usually either cylindrical (13 pieces, including two weights inset with coins), square/rectangular (13 pieces), zoomorphic (six pieces) or triangular (one piece). The decorative copper-alloy insets on at least 24 examples are identified as Insular on stylistic grounds. In four cases, one from Tønnøl and three from Kaupang (see Pedersen 2008, 6.38), the origins of the simple and poorly preserved copper-alloy elements are more difficult to assess, but these should also probably be regarded as of Insular-Viking manufacture. Many examples with plain or undiagnostic copper-alloy mounts are certainly known from apparent Viking contexts in Britain and Ireland such as the Viking camp at Torksey, Lincolnshire (see Hadley and Richards 2016, fig. 20) and as stray finds in Northern and Eastern England (for instance YORYM-6AD518; YORYM-086AAB. See also Table 2). Likewise, two lead weights with glass insets from Kaupang (Pedersen 2008, fig. 6.36) and Heimdalsjordet (Pedersen and Rødsrud 2013, fig. 4) are paralleled in finds from the Viking camps at Woodstown, Co. Waterford (Wallace 2014, 237, fig. 7.80) and Torksey (Hadley and Richards 2016, 49, fig. 20), as well as stray finds from England (for instance YORYM01F154, DUR-31EED4). These are therefore considered here as likely Insular-Viking products., There is a further lead weight from Kaupang which has an inlay of gold (Pedersen 2008, 168), but this specimen is not considered here since it is not paralleled in finds from Ireland or Britain and its background is therefore uncertain.

Insular designs found on the decorative specimens from Norway are traditionally attributed to the Irish-style metalwork tradition of the 8th/ early 9th centuries (Marstrander 1963, 141-3; Wamers 1985, 17-24). In addition to decorative elements, the technique of casting lugs onto the back of some mounts (e.g. Solstad, Husabø) should probably be regarded as an Irish workshop practice which developed sometime after AD 700 (Youngs 2017). Many examples of inset lead weights found in Norway incorporate complete pieces of Insular mounts; several of these may be of ecclesiastical origin (Wamers 1985, 17-24). This includes one T-shaped and four square mounts from Hopperstad, Kvistad, Håland, Berg and Husabø (Figure 2). The four latter examples have slightly raised frames, interlace decoration and a central setting (now missing). Their size (between $20 \mathrm{~mm}-32 \mathrm{~mm}$ in length) and form indicate that they were originally fitted onto house-shaped shrines, as shown by similar-sized mounts on the Monymusk and Shannon shrines (Blindheim 1984, 39-41). On the weight from Husabø (metaldetecting find from 2019, Figure 2A), much of the lead is gone revealing a pair of lugs, positioned on opposing edges on the reverse side. The projecting lugs would originally have passed through the wooden core of a house-shaped reliquary, secured by a single pin, as seen on the Monymusk shrine (see Youngs 2017) and the larger of the two Lough Erne shrines (see Ryan 1989, 135-137 no. 130b). Furthermore, the position of 
the perforated lugs on the corner could indicate that this mount was originally pinned and set at an angle, possibly forming a diamond shape, as seen on the Setnes shrine (Blindheim 1984, fig. 47). Square mounts were also frequently applied on lead weights in Britain and Ireland, as illustrated by a number of close parallels including those from Risby, Suffolk (SF-20A507), Tarrant Hinton, Dorset (DOR-D1CD4E) and Coolure Demesne, Co. Westmeath (Kelly 2007, fig. 42).

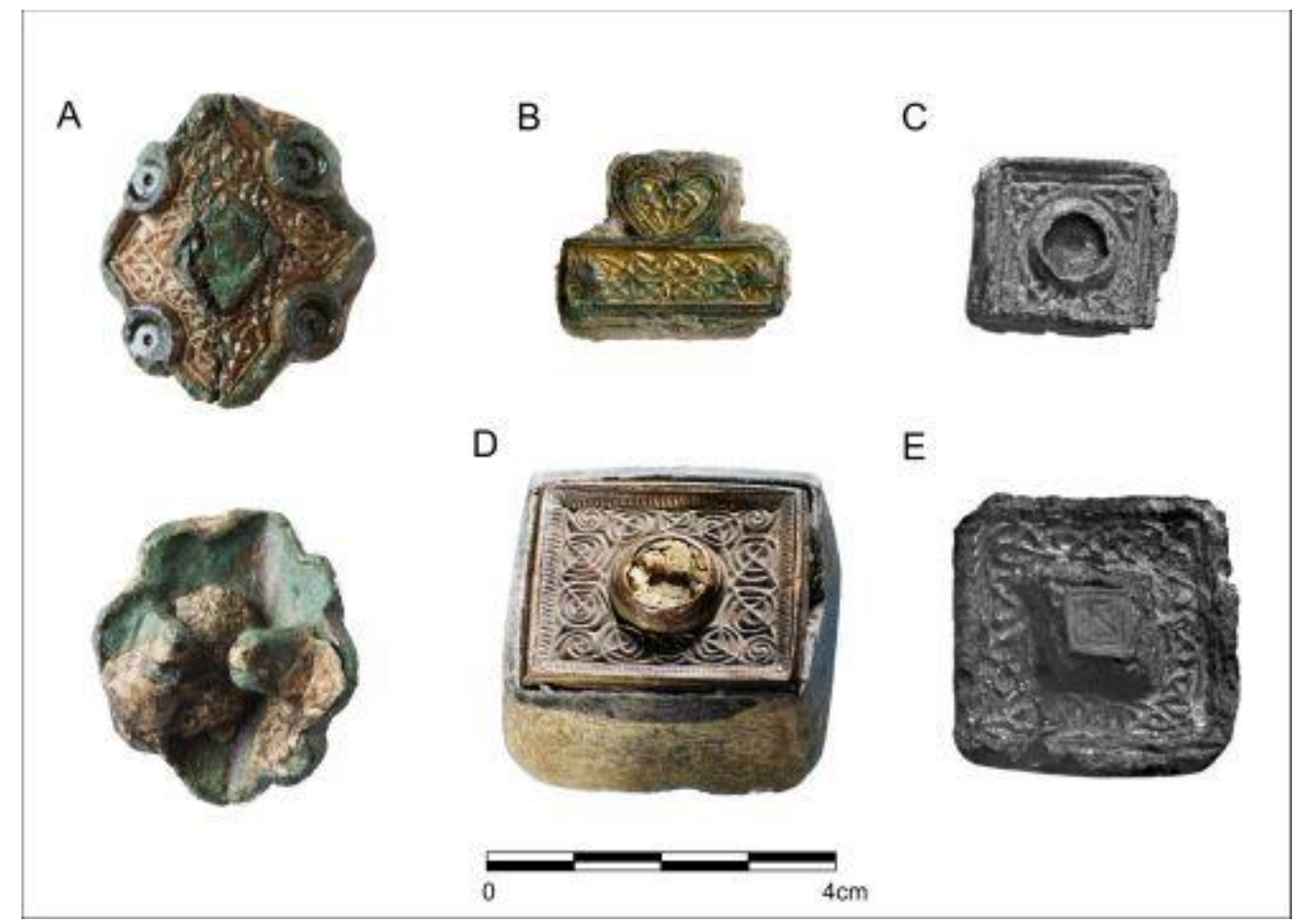

Figure 2: Lead weights incorporating T-shaped and square mounts of likely ecclesiastical origin. A: Husabø, Stavanger (photo: Anette Øvrelid, AMS); B: Hopperstad, Vik (photo: Svein Skaare, UiB); C: Kvistad. Ørsta (photo: Olav Espevoll, UiB); D: Hurum, Berg (photo: Lennart Larsen, National Museum of Denmark); E: Håland, Vindafjord (photo: Olav Espevoll, UiB)

Likewise, the flat circular metalwork on lead weights from Solstad, Missingen and Tjora (between $25 \mathrm{~mm}$ and $43 \mathrm{~mm}$ in diameter) are comparable in form and scale to mounts found on house-shaped shrines (Figure 3). In the Solstad example (Figure 3C), the mount has become detached from the lead weight revealing two original cast lugs on the reverse. The position of the lugs, however, differs from the Husabø example (Figure 2A) since the perforations are not opposing. The Solstad mount would therefore have needed two pins to secure it to its original parent object. 


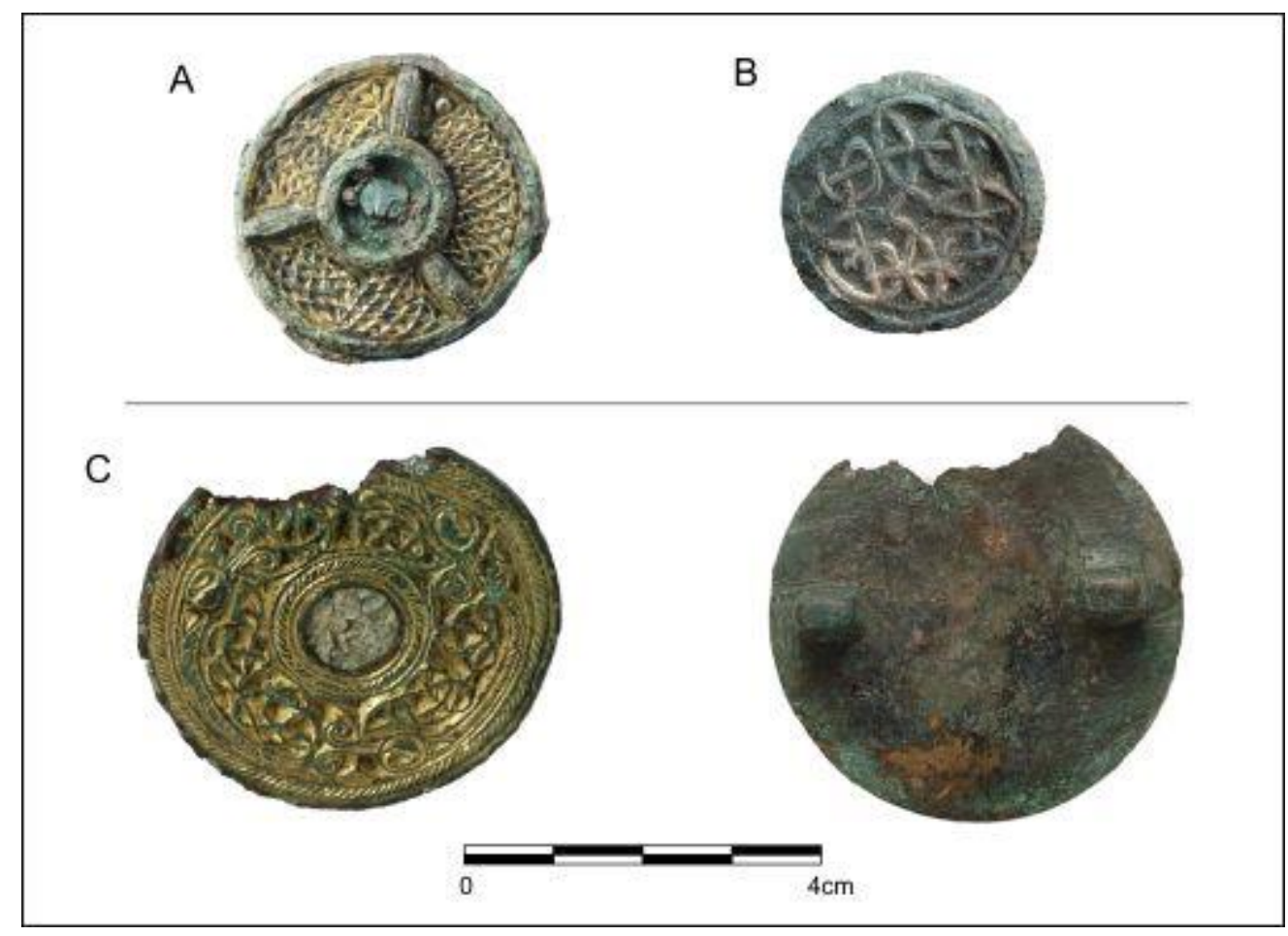

Figure 3: Weights incorporating circular metalwork of likely ecclesiastical origin. A: Tjora, Sola (photo: Terje Tveit, AMS); B: Missingen, Råde (photo: Birgit Marxnier, KHM); C: Solstad, Skaun (photo: Ole B. Pedersen, VM)

A complete mount on a weight from Sandtorg (Figure 4A) is closely comparable to six Insular weights from Ireland (Woodstown, Co. Waterford: Bourke 2010, no. 383; Shanmullagh, Co. Armagh: O Floinn 2014, 183), England (Longtown, Cumbria: LANCUM-1943D1, Figure 4B; Ulgham, Northumbria: NCL-D4EBD5, Figure $\underline{4 \mathrm{C})}$ and Anglesey, north Wales (Llanbedrgoch and Brynsiencyn: Redknap 2007, nos 42 and 43). All these examples have the same square form and a geometric pattern comprising one or four central squares, flanked on each corner with L-shaped cells originally filled with enamel or millefiori. As pointed out by Ó Floinn $(\underline{2014}, 183)$, these mounts probably belong to a group of 'Celtic' enamelled harness fittings discussed by Graham-Campbell (1986). The original function of another three enamelled insets from Setnes, Kvistad and Torland (between $26 \mathrm{~mm}$ and $47 \mathrm{~mm}$ in diameter) are difficult to determine. Those from Setnes and Kvistand carry a similar pattern of four triangular panels which form a cross where they conjoin (Figure 4D, Figure 4E); both have a circumferential border encircling the cross. These mounts have a close parallel in a find from the Shanmullagh assemblage from the River Blackwater (Bourke 2010, 58 no. 241). The third example, from Torland, has a more complex geometric arrangement of Lshaped triangular panels (Figure 4F). Most of these panels were probably once filled with enamel, but eight retain chequered millefiori. In addition to those with a circular form, a recently discovered example from Elgestad Vestre, Færder bears a wellpreserved rectangular and deliberately fragmented inset, with T-shaped panels filled with yellow enamel set against a red background. (This specimen was not conserved or fully catalogued at the time of writing and is therefore not illustrated.) 


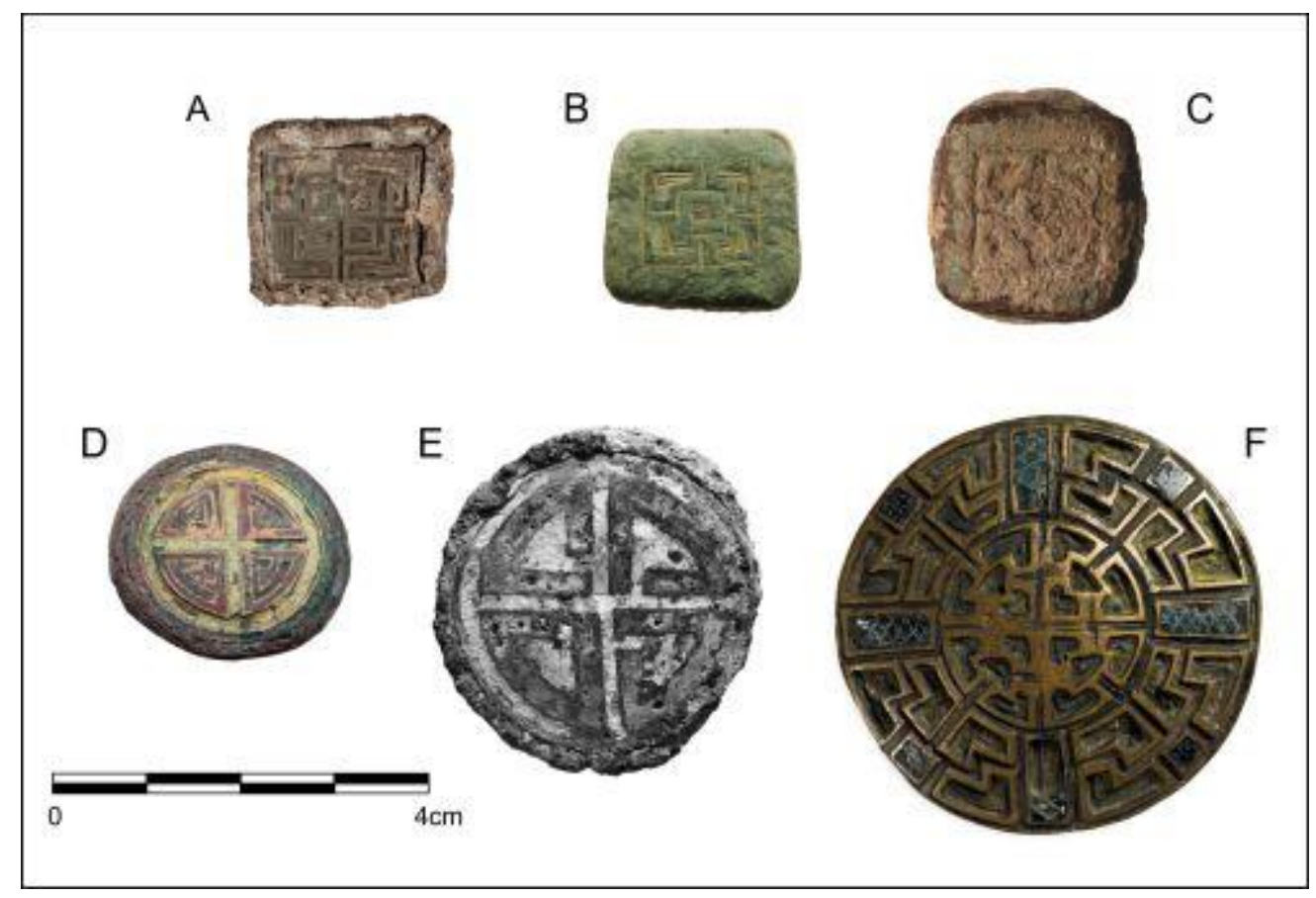

Figure 4: The inset on the weight from Sandtorg, Harstad $(A)$ has close parallels in a number of finds from Britain and Ireland including those from Longtown, Cumbria (B) and Ulgham, Northumbria (C). Other enamelled examples include the finds from Setnes, Rauma (D), Kvistad, Ørsta (E) and Torland, Hå (F). (Photos by Julia Dammann, UiB (A); Portable Antiquities Scheme/Trustees of the British Museum (B and C); Ole B. Pedersen, VM (D); Olav Espevoll, UiB (E); Svein Skare, UiB (F))

Six zoomorphic weights represent a very distinctive group amongst the decorated lead weights (Figure 5 ). These comprise a find from Setnes in the form of a four-footed animal (Figure 5C); a bird-shaped example from Kaupang (Figure 5B; Pedersen 2008, 171); a mount with an animal head on a weight from Aalgaard (Figure 5F) and a weight with an inset formed like 'an animal head, with a strongly upwardly bent snout' from Hopperstad (Figure 5A; Sørheim 2011, 40). Sørheim suggests that the latter mount may derive from a house-shaped shrine. The weight from Aalgaard has close parallels in Britain and Ireland, including a well-known find from a Norse burial at Islandbridge in Dublin (Harrison and Ó Floinn 2014, fig. III. 269) and a further example from the Viking camp at Torksey, Lincolnshire (Hadley and Richards 2018, fig. 2, Torksey Other_509-1). Two further weights, from Hurum and Kaupang, are in the shape of animal heads (Figure 5D, Figure 5E; Pedersen 2008, 175-7). The latter comes from the ridge of the roof on a house-shaped reliquary (Wamers 1985, 18) and it is possible that the Hurum example comes from a similar object. While that from Kaupang is filled with lead, the Hurum weight is hollow underneath, with no evidence of lead. It was, however, originally discovered inside a balance scale together with two other weights, which suggests that this was its function (Pedersen 2008, 176). 


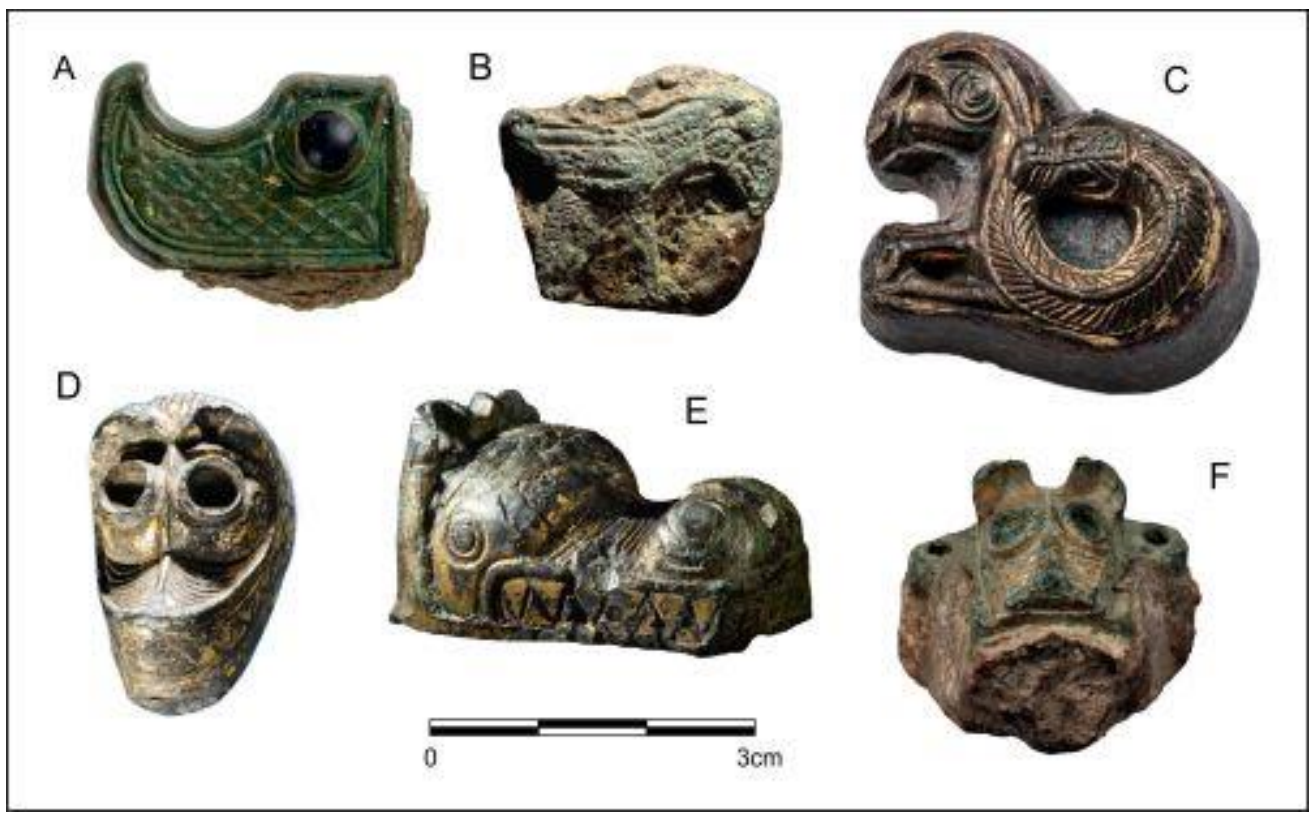

Figure 5: Zoomorphic weights from Norway. A: Hopperstad, Vik (photo: Svein Skaare, UiB); B: Kaupang, Larvik (photo: Eirik Johnsen, KHM); C: Setnes, Rauma (photo: O.B Pedersen, VM); D: Hurum, Berg (photo: Lennart Larsen, National Museum of Denmark); E: Kaupang, Larvik; F: Aalgaard, Lillestrøm (photos E and F: Eirik Johnsen, KHM)

The decoration on the remaining Norwegian weights consists of deliberately fragmented metalwork. Some of these, such as those from Hol, Sunndal (Figure 6A) and Asker Østre (Figure 6E), are too small to determine the nature of their parent object. This is also the case for many examples in Britain and Ireland where the insets comprise fragmented rather than complete pieces of metalwork (for some published examples see Ó Floinn 2014, 184-7; Bourke 2010, fig. 45 nos 375 and 377; Kelly 2007, fig. 42 nos 2003:35 and 2003:37; Hadley and Richards 2018, fig. 2). Nonetheless, at least one, possibly two, of the fragmented insets on the Norwegian lead weights are probably from Irish bridle-mounts of 8th- or early 9th-century manufacture. This includes a recent discovery from Mære (Figure 6C) where the inset is a T-shaped projection from a harness mount, with a close parallel in a complete example from Berdal, Vik (see Wamers 1985, taf. 24, no. 5). In England, at least four metal-detecting finds have Tshaped projections from similar mounts (SUR-569A64, Figure 6D; NMS-

4CF1B6, SWYOR-3903E4; LEIC-09D1C8) which are fragmented in the same way as the Mære example. These may have been prepared as settings for lead weights. Likewise, a circular setting on a weight from Kaupang (Figure 6B) is a close match to the central piece of a harness mount from Lime (Wamers 1985, pl. 6), although Ó Floinn $(\underline{2014}, 176)$ has highlighted its similarity with a brooch terminal from Woodstown. 


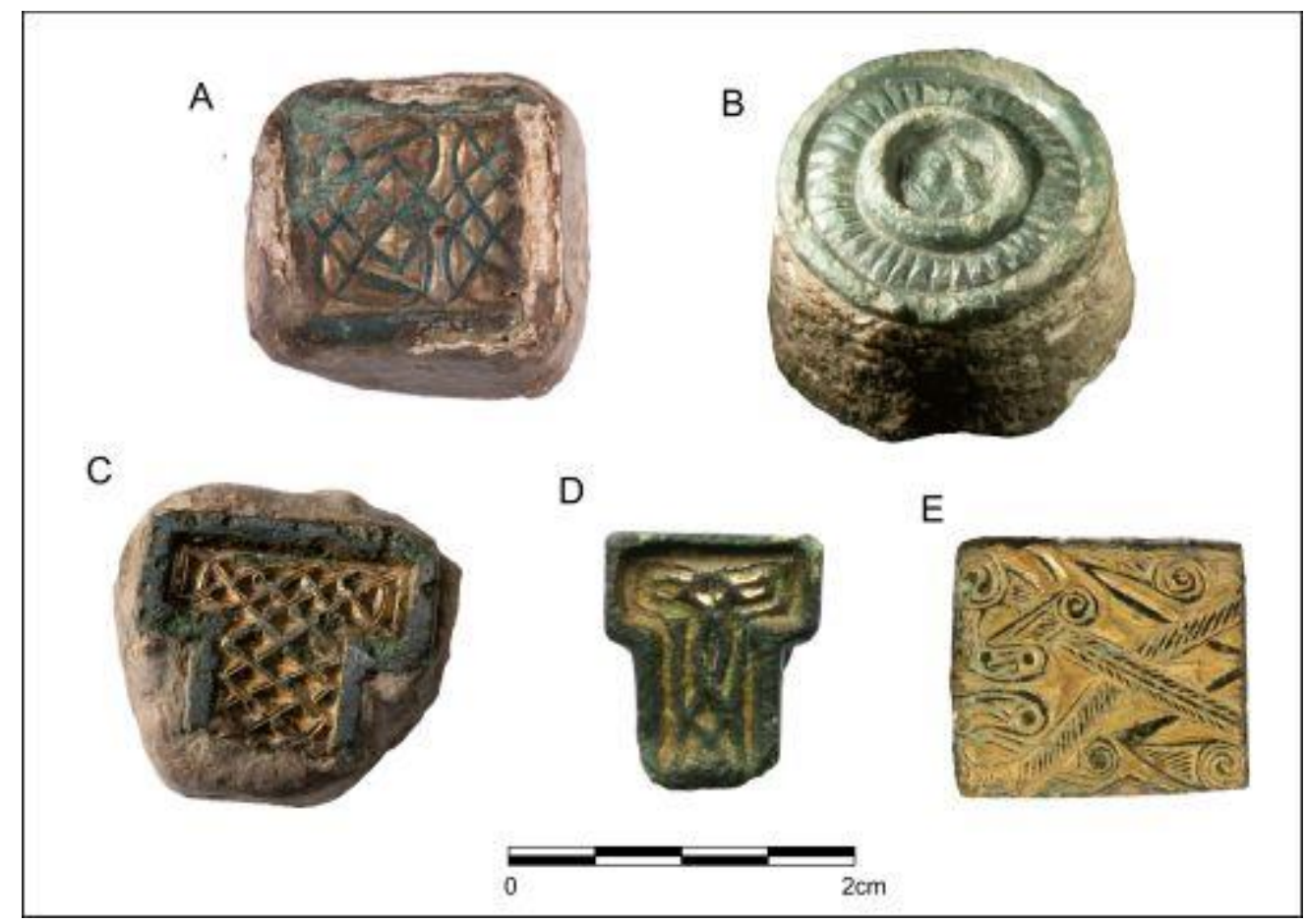

Figure 6: Examples of weights incorporating fragments of Insular metalwork. A: Hol, Sunndal; B: Kaupang, Larvik; C: Mære, Steinkjer; D: Guildford, England; E: Asker Østre, Asker. Several fragmented pieces of metalwork from England, such as the example from Guildford (D, SUR-569A64), may have been prepared for use as settings on weights. (Photos by Åge Hojem, VM (A and C); Eirik Johnsen, KHM (B); Birgit Maixner, KHM (E); Portable Antiquities Scheme/Trustees of the British Museum (D))

Finally, both the original use and geographical origin of a fragmented, openwork fragment on a weight from Håland is difficult to affirm, but it does have a near-identical parallel in a metal-detecting find from Gisburn in Lancashire (LANCUM-107126) (Figure 7). The design is unclear, but it has been suggested that it 'may represent two interlacing animals, perhaps birds seen in profile' (Noon 2014).

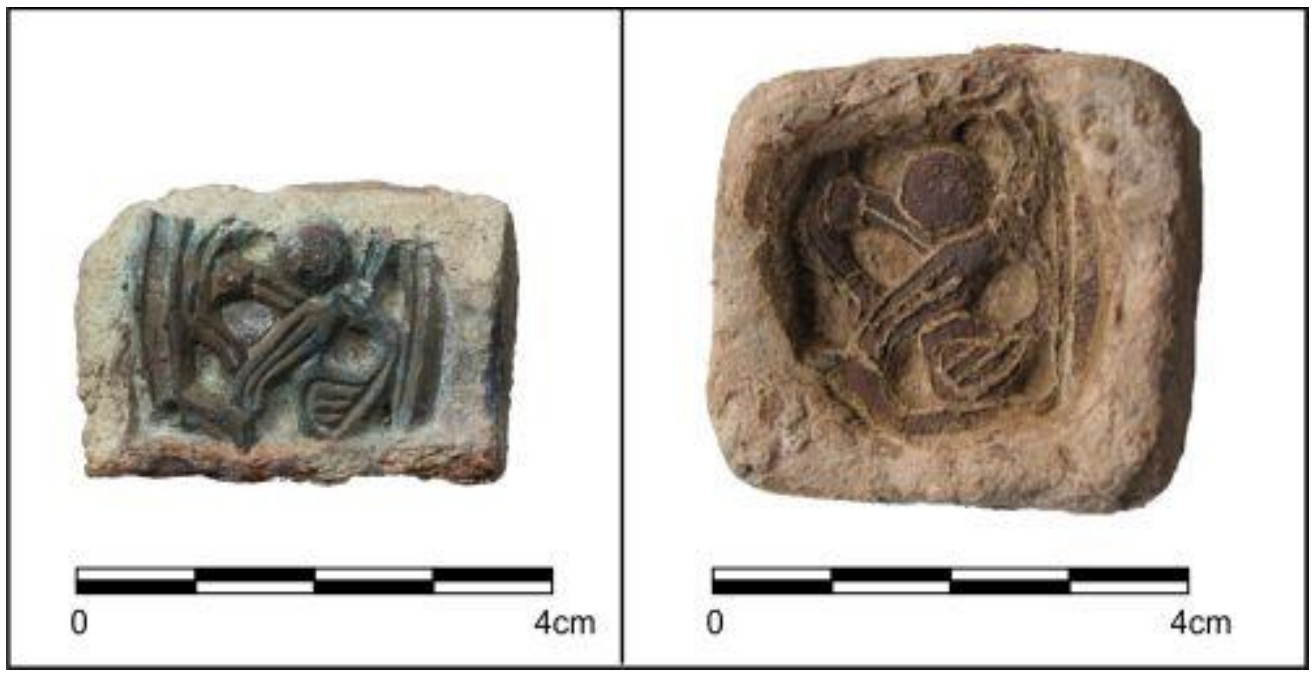

Figure 7: The mounts on the weights from Håland, Vindafjord (left) and Gisburn, Lancashire (right) are nearly identical. (Photos by Terje Tveit UiB and Portable Antiquities Scheme/ Trustees of the British Museum) 


\section{Circulation and function: the question of Insular-Viking manufacture}

Norway has the highest number of lead weights inset with Insular metalwork and coins in modern-day Scandinavia. However, this type of weight is also found in other areas of Scandinavia, with six published examples from Denmark and one from Sweden (Baastrup 2013a, 12; Wamers 1985, 99 no. 154). The example from Sweden is a stray find from Lund, while the Danish examples are either stray finds or metal-detected finds, some of which are associated with settlements (Baastrup 2013b, 172-82). It should also be noted that while the Norwegian overview includes finds collected up to 2019, the figures for the Swedish and Danish finds are taken from publications in 1985 and 2013, respectively. Different metal-detecting practices can also create bias in the Scandinavian finds' distribution: private metal-detecting is allowed in Norway and Denmark but not in Sweden, and until quite recently, it was far more widespread in Denmark than Norway. Even when this is taken into consideration, it seems apparent that inset weights were brought more frequently into Norway than other parts of Scandinavia. This is perhaps not surprising, considering that it is also where the largest quantity of Insular finds is known (Wamers 1985; Heen-Pettersen 2020).

While the number of inset lead weights from the Norse homelands has increased in recent years, it is in Britain and Ireland that the greatest quantity is found. Information derived from the Portable Antiquities Scheme (PAS), online museum collection databases, and published examples shows that at least 217 examples are recorded from Insular areas, as of June 2019 (Table 2). This includes 154 finds from England, 5 from Wales, 45 from Ireland and 13 from (southern) Scotland. The actual amount is likely to be considerably higher since an unknown number of weights have been dispersed without being recorded. This is especially true for the British and Irish material, since private metal-detecting is permitted in England, Scotland, Wales, and Northern Ireland, but is illegal in the Republic of Ireland. Within Britain there are also regional variations in the laws on metal-detecting and in the intensity of metal-detecting and modern-day constraints that, to some extent, affect the distribution pattern.

Consequently, the different metal-detecting practices and policies on either side of the North Sea will result in the finds being subject to some geographical bias (Kershaw 2013, 13-19). Moreover, further weights from Britain, Ireland and Norway have impressions which may mark the loss of embedded objects (Pedersen 2008, 171; Bourke 2010, 26; see also NLM-8F9302, LANCUM-4AF424, NLM-26D4B9, NLM79C4DF for some examples) but these are not included in this article. 


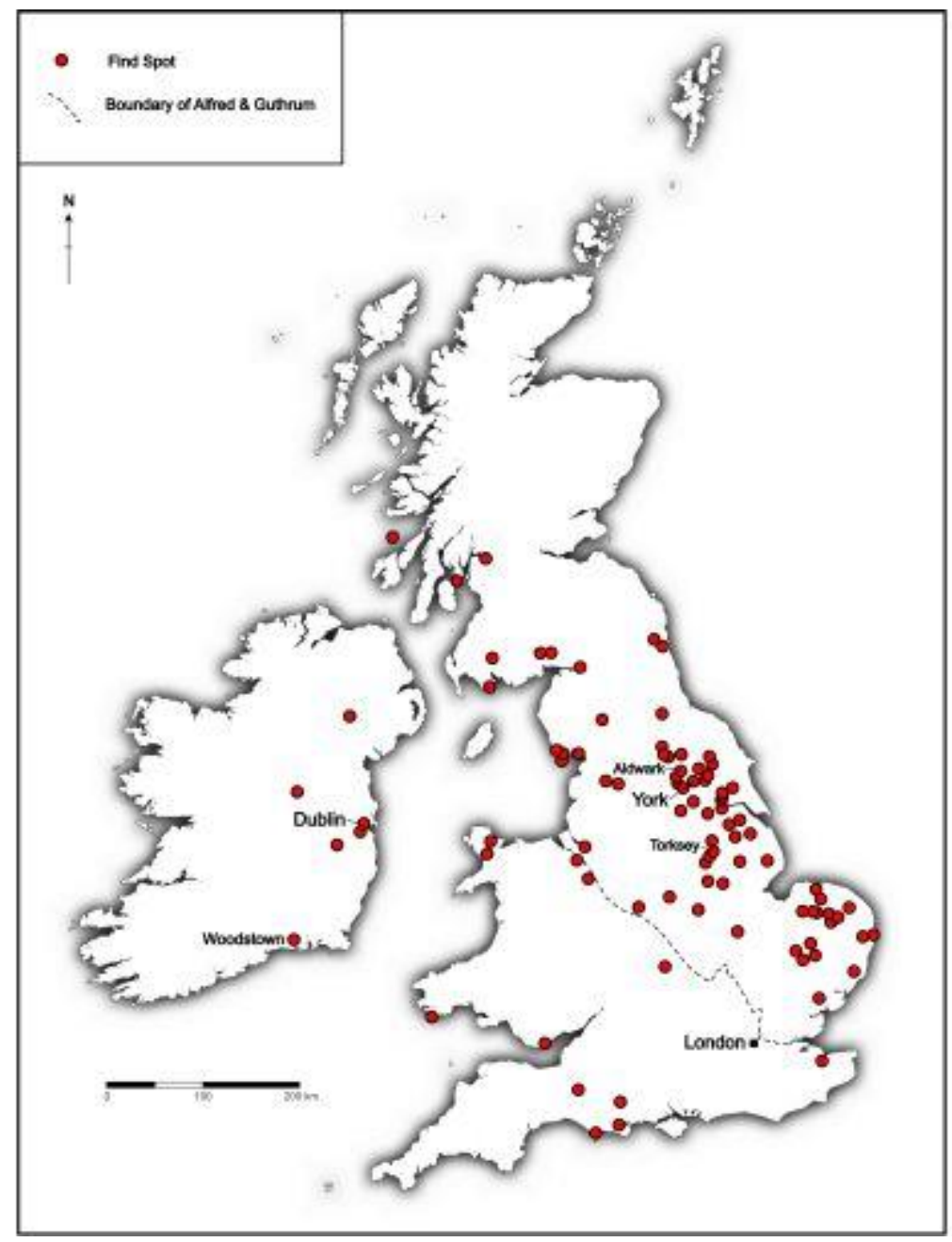

Figure 8: Distribution of inset lead weights from Britain and Ireland. The dotted line represents the border established between King Alfred of Wessex and King Guthrum of East Anglia in the later 9th century. This is generally used to mark the southern border of the Danelaw (Map by Philip Wood)

Nevertheless, it is in Northern and Eastern England where most finds are currently known (Figure 8). These are mainly derived from metal-detecting or are stray finds, and the vast majority fall broadly within the area often referred to as the Danelaw, an anachronistic 11th-century term (Hadley 2012). It is used here as a geographical term comprising the northern, central, and eastern regions of Anglo-Saxon England, which were occupied and settled by Scandinavians in the late 9th and 10th centuries (following Kershaw 2013, 3-4). In this area, the Scandinavians largely operated a bullion (weightbased) economy. As discussed below, finds of weights from the Danelaw are therefore generally believed to indicate a Scandinavian presence or activity (see Williams 2015, 101-14; Hadley and Richards 2016; Hadley and Richards 2018). The same is true for the Irish finds:

- 18 'copper-alloy encased' weights came from the Viking town of Dublin (Wallace 2016, 361);

- 8 inset lead weights and 1 coin inset lead weight (the only example known from Ireland; unlocated but possibly a Shannullagh find) form part of the Shanmullagh assemblage (Bourke 2010, 26);

- 3 were found at the Coolure demesne crannog (Kelly 2007, fig. 42); 
- at least 8 examples (six with metalwork and 2 with glass/crystal) are out of context finds from the Viking camp at Woodstown, Co. Waterford (Ó Floinn 2014, $181-5$, figs 7.76 and 7.80 );

- 1 specimen was recently recovered from a ditch within an area of early medieval activity in Craddockstown North, Co. Kildare, south-west of Dublin (Ní Cheallacháin 2019, 36-7);

- 9 examples are also known from the Norse burial site at Islandbridge, outside Dublin. While the exact circumstances of their discovery are somewhat uncertain, they are believed to derive from at least two, possible three burials (GrahamCampbell 1980, cat. no. 308; Harrison and Ó Floinn 2014, 443-73).

Taken together, the relatively small number of copper-alloy inset weights from Scandinavia when compared with those from Britain and Ireland, and the predominant use of Insular metalwork as decoration, is in keeping with the suggestion advanced by a number of researchers that these are of 'Insular-Viking manufacture' (Kruse 1992, 82; Ó Floinn 2014, 188-9; Williams 2015, 111-12; Kershaw 2016, 96-7, Hall et al. 2020, 84). Finds of small decorative fragments from Viking sites in Ireland and Britain, such as Woodstown, Co. Waterford and Torksey, Lincolnshire, which appear to have been prepared as settings for these weights, support this view (Ó Floinn 2014, 166; Hadley and Richards 2016, 53; see also the T-shaped form mentioned above). In terms of the metalwork itself, it is not possible to give a detailed overview of this material here, but as already noted above, many examples from Britain and Ireland have close parallels in the Norwegian material and they clearly belong to the same custom. As with the Scandinavian examples, many Insular weights incorporate Irish-style metalwork (Ryan 1989, 142; Kershaw 2016, 97), although the art-styles are sometimes difficult to distinguish due to their fragmented nature. A small number of lead weights also carry probable Anglo-Saxon metalwork (for example, an item from Weymouth, Dorset $\mathrm{BH}-$ 1DA0A5 and one of the seven lead weights from Kiloran Bay, Scotland: GrahamCampbell 1980, cat. no. 307), while four examples, three of which consist of female jewellery, incorporate Scandinavian metalwork (see SWYOR-8A1BCA; Kruse 1992, 81; Kershaw 2013, 226; Graham-Campbell 1980, cat. no. 308).

In dating terms, a number of finds from Britain and Ireland can be placed within a relatively narrow timeframe. These include 37 inset lead weights from the Viking camp at Torksey, Lincolnshire, where the Great Army is recorded to have over-wintered in AD 872/873 (Hadley and Richards $\underline{2016}, 23,39,49$ ). The following year the army split into two, suggesting the 12 inset weights from Aldwark (also known as ARSNY) are associated with the section of the army, led by Halfdan, which turned northwards to Northumbria in the mid-870s (Hall et al. 2020, 81). A richly furnished burial at Kiloran Bay, Colonsay, Inner Hebrides, is the only grave from Britain to contain decorated lead weights and has, based on the range of grave goods, been dated towards the end of the 9th century (Graham-Campbell and Batey 1998, 122). Likewise, the Talnotrie hoard, Kirkcudbright (southern Scotland), which contained one inset weight, has a suggested deposition date of the early or mid-870s, based on the coins found alongside it (GrahamCampbell and Batey $\underline{1998}, 122)$. A similar date is probable for weights inset with coins, for which production appears to have been 'concentrated in the first decade or so after the arrival of the micel here in England in 865' (Hall et al. 2020, 23). In Wales, two inset lead weights from an enclosed settlement near Llanbedrgoch, Anglesey are ascribed to a late 9th- or early 10th-century date (Redknap 2007, 59). From Ireland, the topsoil of the former Viking camp at Woodstown, Co. Waterford (Ó Floinn 2014, 181-3) yielded at least eight inset lead weights. The archaeological evidence indicates a 9th-century occupation for this site, but the camp was probably first occupied 'towards the middle, 
rather than at the beginning of the century' (Harrison 2014, 16). Finally, while not specifying the decorated examples directly, most lead weights from Dublin derive from 10th- and 11th-century layers (Wallace 2014, 224). These may therefore be primarily associated with use in the period after the Vikings returned to Dublin in AD 917, following their expulsion from the town in AD 902. Overall, the evidence indicates that this material phenomenon developed in Insular areas sometime in the second half of the 9th century, possibly from the AD 860s/70s and continued in use for two to three generations (Hall et al. 2020, 16-23). These observations strongly suggest that the 'undated' graves with inset weights from Norway (Asker and Vik) and those that can only be assigned a very broad date range (such as the Hopperstad burial), should also be attributed to the late 9th century at the earliest. The same is true for the stray finds and metal-detecting finds, which probably arrived in Norway within the same broad chronological timeframe.

While it has been proposed that undecorated lead weights could serve as low-value currency suitable for 'day-to-day transactions' (Williams $\underline{2015}, 113$ ), this does not seem to have been the case for the inset examples when based on the evidence from burials in Norway, Ireland and Scotland. In these examples, inset lead weights almost exclusively formed parts of weight sets and were accompanied by balance scales (see above). This suggests that inset weights were primarily used with balances as part of bullion transactions. In addition to precious metals, especially silver, these transactions could also involve other metals such as copper alloy and lead (Williams 2015, 115). Such equipment may also have been used in a wide variety of forms of exchange in the Viking milieu, for example accurate loot-sharing and the collection of bails and taxes (Pedersen 2008, 159-61). However, payment in bullion may not always have had a strictly economic function, being also transacted and consumed within broader and sometimes overlapping social settings, such as gift-giving and the exchange of bride wealth (see e.g. Pedersen 2008; Sindbæk 2011; Sheehan 2013). Considering the high number of gaming pieces from the Viking camps at Torksey and Aldwark, perhaps bullion was also exchanged in connection with gambling (see Hadley and Richards 2018, 1-4)? Some Scandinavian scholars have suggested that balances are Insular, due to their tinned surface and the fact that the pans often feature marigold ornament that is also found in Ireland (Petersen 1940; Jondell 1974). Graham-Campbell $(1980,88)$ has, however, cautioned against this view since 'there is yet little evidence to substantiate or refute this hypothesis'. Due to the uncertainty regarding their place of manufacture, balances are not included in the discussion here.

In terms of function, it is notable that while lead weights are a common archaeological find in the Viking world, the inset type represents only a small category within this larger corpus of material. For instance, the Viking town of Kaupang (including finds from the town's cemeteries) have yielded at least 410 lead weights (Pedersen 2008, 121), only seven of which were inset with copper alloy and only four of these are definitively or likely Insular (C52507/67k, C52507/69Plo, C52517 419, C52517 2168). Furthermore, while two inset lead weights were recently found in Hedeby by metal-detecting (Volker Hilberg, pers. comm.; Figure 9), such weights are absent from the towns of Ribe and Birka (according to the national overviews in Wamers 1985 and Baastrup 2013a). At the Viking longphort at Woodstown, out of a total of 217 lead weights, only six were decorated with Insular metalwork and two with glass/crystal (Ó Floinn 2014, 181-5), while 37 of the 244 lead weights from Torksey, Lincolnshire were inset with metalwork and glass (Hadley and Richards 2016, 39, 49). (Some of the Woodstown weights have tiny copper-alloy pellets on the surface of the lead or nails driven through the lead (Wallace 2014, 226), but these are not included in the group of inset weights discussed 
here. A detailed overview of the Torksey material has not been published and it is therefore possible that the insets may include additional types.)

These decorated inset weights therefore form a corpus which is visually distinct from that of other forms of weights in Viking Age society. While the decorated weights have similarities in form, the metalwork utilised on each piece is often unique and consequently easily recognisable. Williams $(1999,34)$ has argued that an important function of the decoration was to customise the weights, so that the individual owner could easily identify their own tools during transactions. In such settings, all types of decorated metalwork, even mere scraps, could serve to personalise weights to avoid confusion or fraud (Hall et al. 2020, 23)

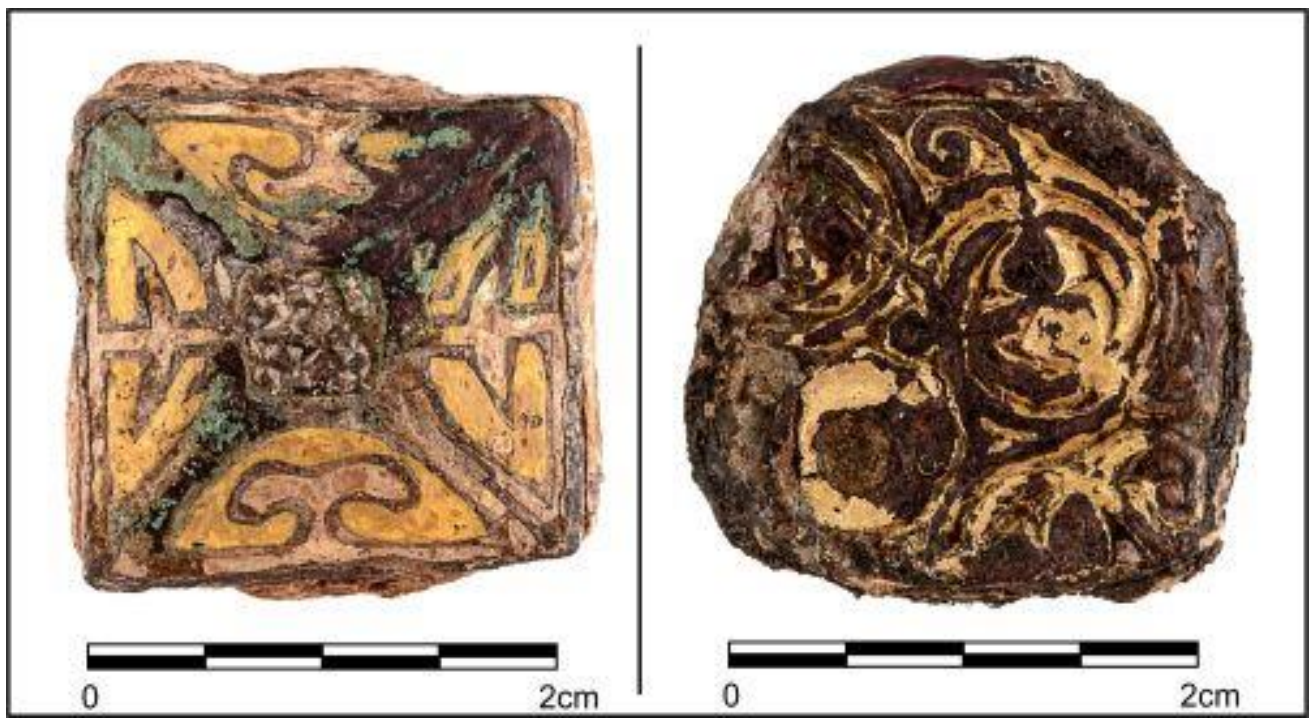

Figure 9: Two inset lead weights recently discovered in Hedeby by metal-detecting. (Photo: The Archaeological Museum Schloss Gottorf)

\section{Different fragmentation practices on either side of the North Sea}

As shown above, the inset lead weights were decorated with both complete and fragmented pieces of decorative metalwork, but how does this custom relate to the wider Norse practice of utilising Insular metalwork?

Along with lead weights, the presence of other types of Irish-style metalwork within the Danelaw is often interpreted as evidence of second-hand exchange of looted material (Youngs 2001, 254; Kershaw 2016, 98-100), and such metalwork is often found on sites that have lead weights. This is especially true of deliberately fragmented pieces which were recovered in large numbers from the Viking camps at Torksey and Aldwark, as well as a number of other places either visited or settled by the Great Army and its offshoot in the late 9th and early 10th century (Hadley and Richards 2018; Richards and Haldenby 2018; Hall et al. 2020, 59-61). Some of this material was probably intended to be melted down, as indicated by the increasing number of copper-alloy ingots found in the Danelaw. This suggests a value as raw material, but ingots and other pieces of copper-alloy metalwork may, as noted above, have also played a part in low-value 
bullion transactions as 'a form of commodity money' (Williams $\underline{2015}, 113-14$; Pestell 2013, 249-50; Hadley and Richards 2016, 47-50).

Insular mounts are also found in large numbers in Norway (approx. 200 pieces), but there they were mostly reworked and used as various types of dress ornaments. (Number is as at December 2018 and does not include mounts from sets of horse harnesses, mounts attached to lead weights or metalwork from artefacts which were probably used as intended.) While most of the datable pieces can be attributed to the late 8th or 9th century (61 examples), a smaller number (20 pieces) were deposited in the first half of the 10th century. Although complete pieces are the norm, the corpus of 'mount-brooches' also includes a small number of deliberately fragmented pieces (Aannestad 2018, 8; Figure 10). Morphological details show that some are carefully cut with a very deliberate consideration for the original pattern. For instance, a specimen from Alstad, Levanger (Figure 10C) derives from an Anglo-Saxon mount which has been cut in half, producing two matching ornaments. Likewise, the mount from Votne (Figure $\underline{10 \mathrm{~B}}$ ) has been carefully shaped to ensure that two complete animals, in relief, form part of the ornament. The symmetrical precision with which other mounts, such as those from Orre, Torske and an uncertain location (Figure 10D, Figure 10E, Figure 10A) have been divided, is also not coincidental. Studies have shown that these were largely reused in the same way as complete pieces: as brooches or other types of dress ornaments such as pendants or belt decorations. As distinctive elements of Norse costume, such Insular metalwork may have been deliberately used to signify a household's involvement in successful overseas expeditions and the status accrued by a returning member of the family (Aannestad 2015; Heen-Pettersen 2018).

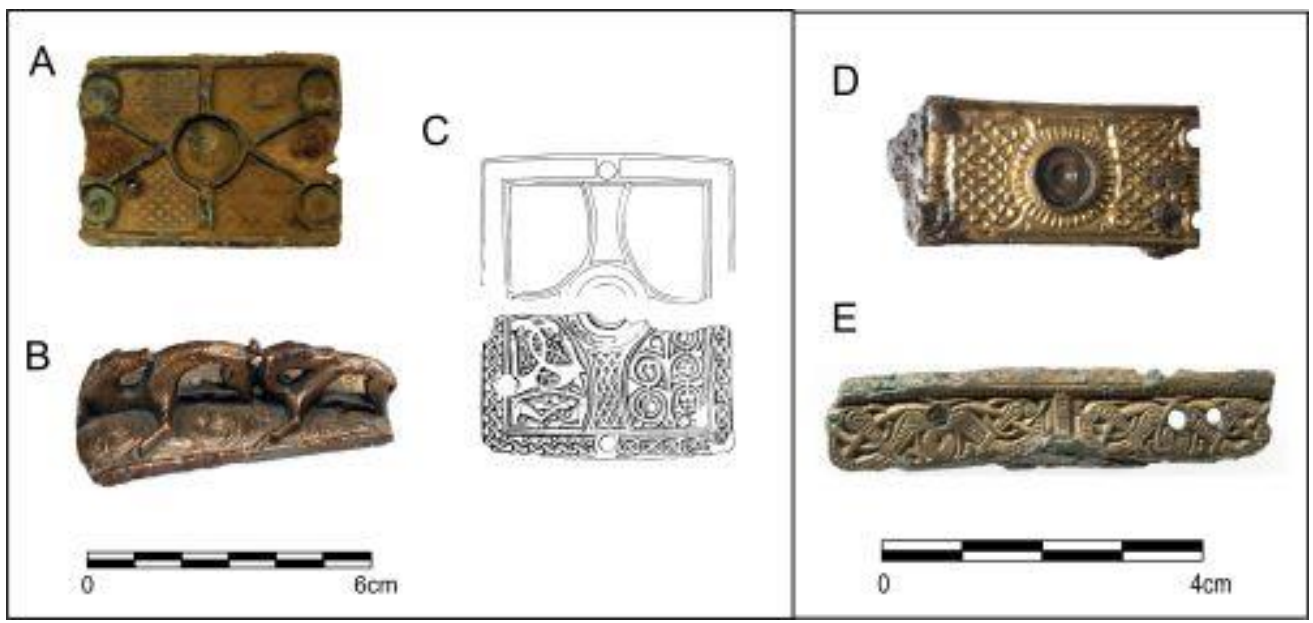

Figure 10. A selection of 're-fashioned' mounts from Norway. A: Uncertain location, Norway (photo: the author); B: Votne, Lindås (photo: Svein, Skare, UiB); C: Alstad, Levanger (drawing: Per Rasmussen); D: Orre, Klepp (photo: Svein, Skare UiB); E: Torske, Sunndalen (photo: Åge Hojem, VM)

In contrast to the Norwegian material, much of the fragmented Insular metalwork associated with Viking activity in Britain and Ireland has been cut without regard for the original decoration or the symmetry seen on the Norwegian material (see for instance Bourke 2010; Hadley and Richards 2016, 51-3). With a few exceptions, most of this metalwork also lacks clear signs of reworking into dress ornaments. Consequently, the differences in terms of deposition and morphology on either side of the North Sea indicate that it is not appropriate to view all fragmented pieces of Insular metalwork in the same manner. Instead, it is suggested here that deliberately fragmented pieces of 
metalwork may be divided into different categories: those that are 're-fashioned, i.e. carefully cut into pieces and reworked into dress ornaments, and those that appear to have been fragmented as hack silver and other metals intended for reuse as scrap or as bullion commodity. Unfortunately, while the latter group appears to be mainly associated with late 9th- and early 10th-century Viking activity (based on the Insular evidence), only two 're-fashioned' pieces come from contexts datable to the early 9th century and early 10th century, respectively. Therefore we cannot be certain whether this phenomenon belongs mainly to the early or later part of the Viking Age.

Furthermore, distinguishing between these categories is not always straightforward, especially when finds have been damaged post-deposition. This is especially true for many of the recent metal-detecting finds. It may, however, be a useful index for identifying objects intended as scrap metal or low-value bullion, and it is notable that few of the mounts from Norway appear to have received the same crude treatment as that seen, for instance, on the metalwork recovered from the Viking camps at Torksey (Hadley and Richards 2016, fig. 23) and Aldwark (Hall et al. 2020, fig, 19). There are some notable exceptions, exemplified by the recently discovered mounts from Skånes, Levanger (metal-detecting find 2016, Figure 11A), Sve, Vågå (metal-detecting find 2014, Figure 11B) and the two fragments of penannular brooch hoops from Nes, Fauske (metal-detecting find 2016, Figure 11C) and Kaupang (from a settlement deposit, Wamers 2011, 82-3, Figure 11D). All of these are small, with lengths ranging between $17 \mathrm{~mm}$ and $33 \mathrm{~mm}$, and have been cut by a sharp tool, suggesting they were fragmented for other purposes than dress ornaments before they were lost. Secondary perforations and nails on the fragments from Kaupang and Sve are evidence of repair or reworking prior to their final fragmentation, indicating that the metalwork had been circulating for some time before eventually being cut up. The Norwegian evidence for second-hand trading in Insular metalwork is still somewhat limited, however, especially when compared with the relatively extensive material from England and Ireland. Moreover, Pedersen's analysis of non-ferrous metal waste from Kaupang does not indicate extensive reuse of copper-alloy scrap metal $(\underline{2016}, 194)$. Nonetheless, the surge in metal-detecting activity in Norway is likely to uncover further pieces which may have served purposes other than dress ornaments. 


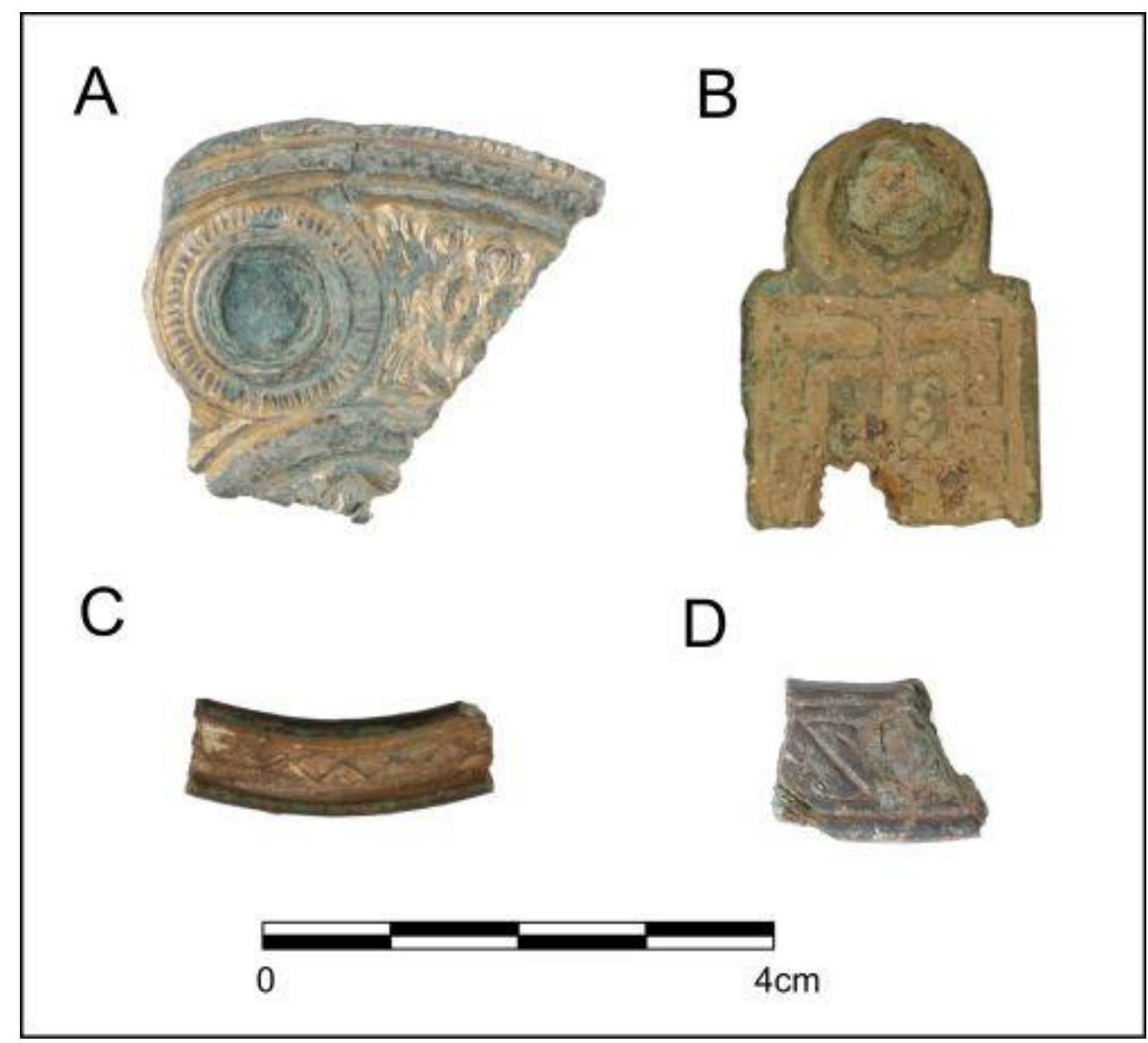

Figure 11: Fragmented pieces of Insular metalwork from Norway, probably used as scrap or bullion. A: Skånes, Levanger (photo: Terje Hellan, VM); B: Sve, Vågå (photo: Birgit Marxnier, KHM); C. Nes, Fauske (photo: Yang Koh, UIT); D. Kaupang (photo: Erik Johnson. KHM)

\section{Discussion: potential connections between Norway and England}

What, then, is the likely historical context for the decorated lead weights and fragmented metalwork that ended up in the Norse homelands?

Even though individual weights have varied biographies and itineraries, overall distribution patterns may give some clues as to the geographical sources of the Scandinavian examples and how they were introduced to Norway. This survey indicates two main areas of circulation: the Irish Sea region and, most commonly, the Danelaw. There are a number of challenges in using the distribution of decorated lead weights as an index to their main regions of use. In addition to the metal-detecting biases already mentioned, lead weights and metalwork are small, portable items that could be carried over some distance. In contrast to the Norwegian examples found in burials, it is presumed that most weights from Scandinavian England represent accidental losses linked to a Viking presence and activities, such as travel, temporary Viking camps, and exchange on various levels (Hadley and Richards 2018; Kershaw 2013, 181-3 advances the same view for finds of Scandinavian jewellery within the Danelaw). Two 
well-preserved weights found at Water Newton, Cambridgeshire (DUR-8BA064) and Sheriff Hutton, North Yorkshire (SWYOR-4F2B32) illustrate the potentially complex itineraries of such objects: the insets on both weights comprise identical circular mounts which may derive from the same parent object (Figure 12). This is further supported by the matching projections, which protrude from the lead on the back. What is more, the dimensions of the weights are almost identical, as are the current weights of $72.30 \mathrm{~g}$ and $72.24 \mathrm{~g}$ respectively. It appears, therefore, that these examples were made into weights on the same occasion and yet were lost more over $200 \mathrm{~km}$ apart.
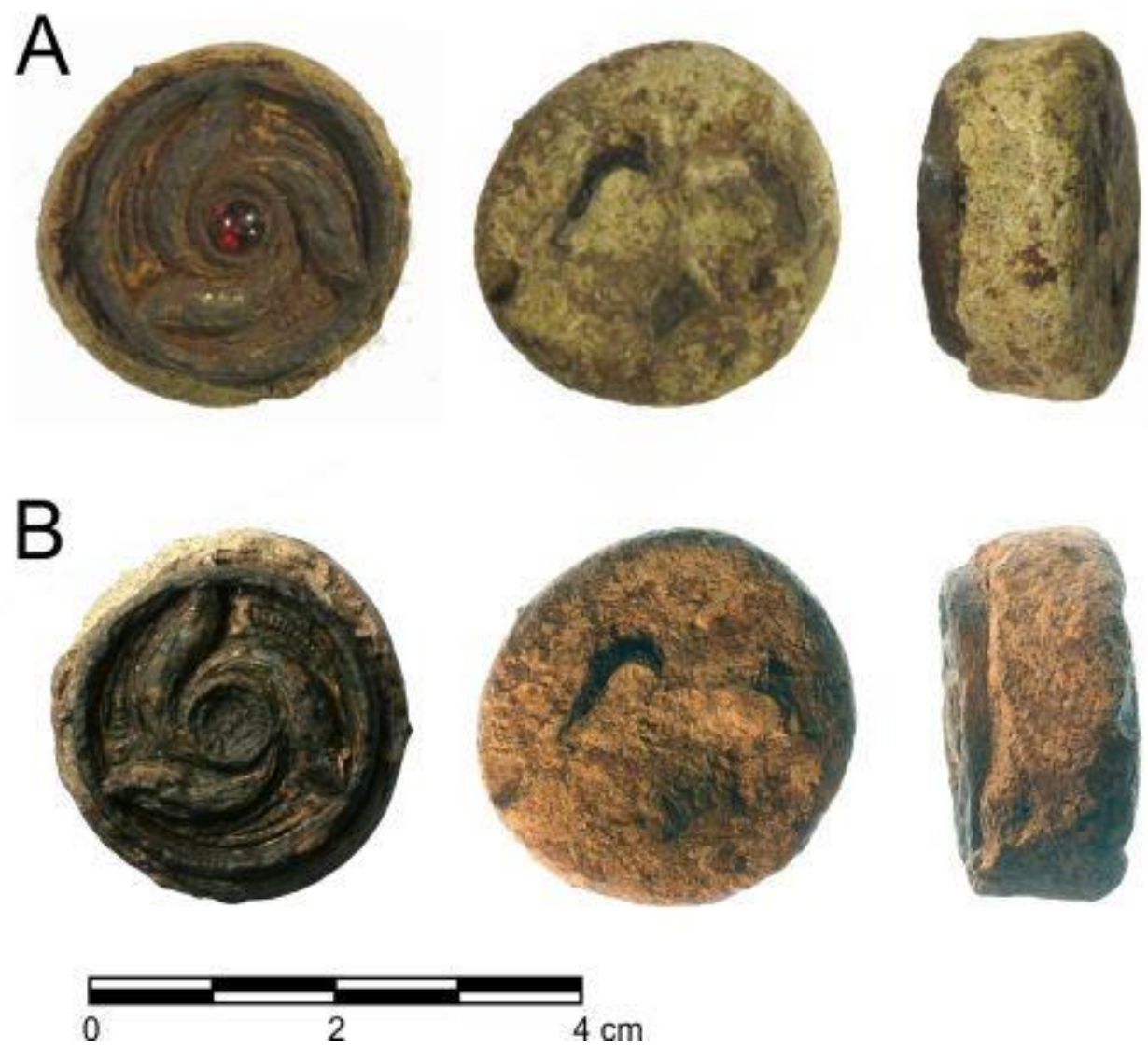

Figure 12: The insets on these two weights from Water Newton, Cambridgeshire and Sheriff Hutton, North Yorkshire, found over $200 \mathrm{~km}$ apart, comprise identical circular mounts which may derive from the same parent object. (Photos: Portable Antiquities Scheme/Trustees of the British Museum)

However, decorated weights are not evenly distributed throughout the Danelaw, indicating that they were used more frequently in certain parts of the Scandinaviancontrolled areas. The distribution indicates that inset lead weights were mostly used (or certainly lost) in the north and east, especially Lincolnshire and North and East Yorkshire (Figure 8 and Table 2). This coherent concentration indicates that Insular metalwork was carried eastwards from Ireland, probably due to links with the Viking kingdom of York and beyond. The close connection between the Viking dynasties in York and Ireland, especially Dublin, is certainly well-attested in Anglo-Saxon and Irish sources, and Vikings from Ireland were also active in other parts of the Danelaw and northern Britain (Downham 2007, 63-175). Finds of Irish-style metalwork, including those used as 
decoration on lead weights, may be direct evidence of such 'pan-Insular' Viking activity (Youngs 2001, 254; Kershaw 2016, 96-100; Hall et al. 2020, 84).

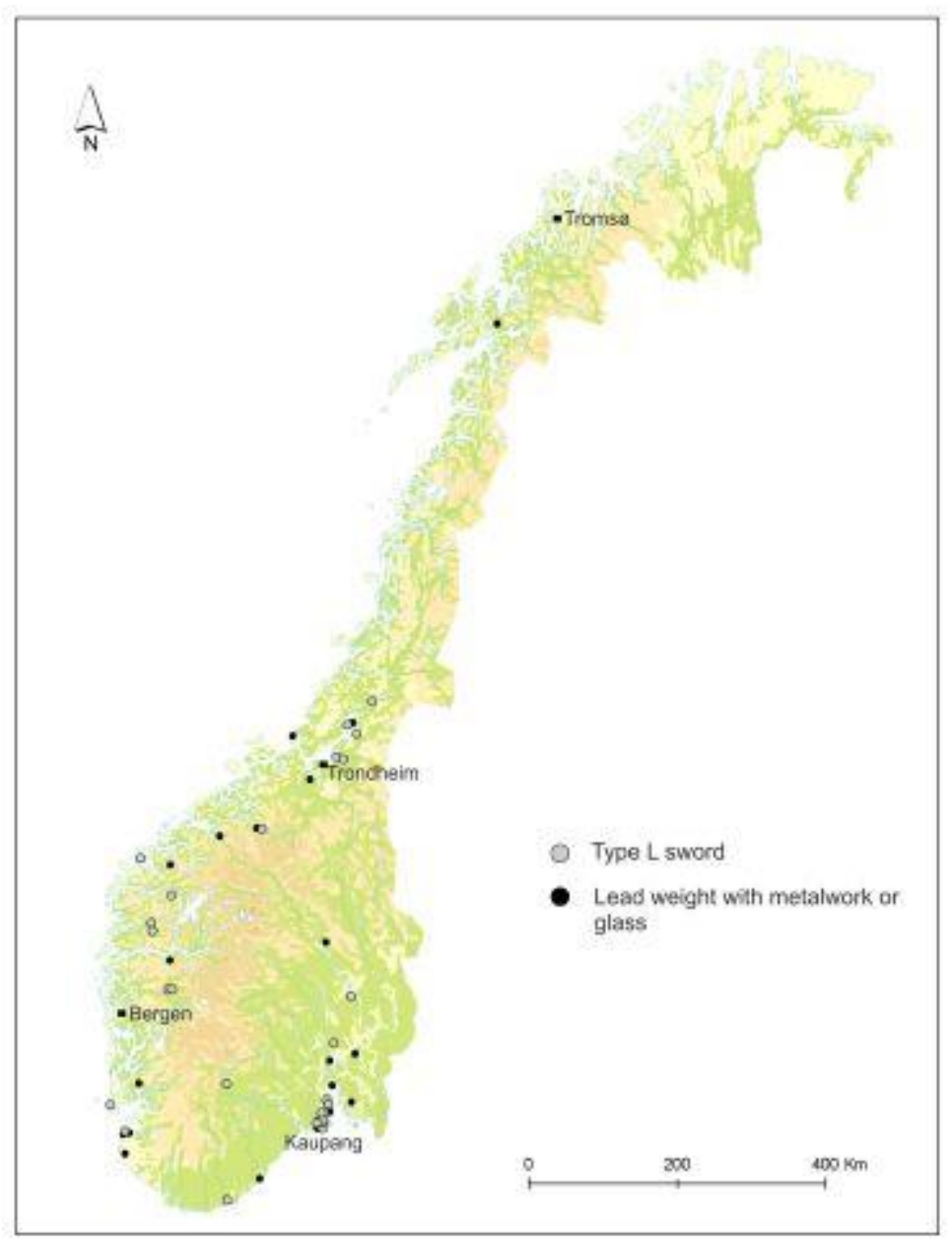

Figure 13: Distribution of Anglo-Saxon swords and lead weights. The distribution of swords is based on Aksdal 2017, catalogue A, with the addition of C13595, C3619 defined as L-types by Androshchuk 2014, 67. This number does not include Aksdal type IV and other specimens which may be locally produced copies. (Map by Aina HeenPettersen)

This wider geographical distribution certainly has implications for how decorative lead weights found in the Scandinavian homelands are regarded. These objects have generally received attention for their decorative, mostly Irish-style metalwork and therefore Irish affiliation (e.g. Sørheim 2011, 40; Mikkelsen 2019, 77), while their potential for providing evidence for integrated contact between Norway and the Danelaw has hitherto gone largely unnoticed. Furthermore, it is notable that the influx of decorated lead weights to Norway happens around the same time as the arrival of Anglo-Saxon swords in the Norse homelands (Petersen (1940) type L: 26 known specimens; Figure 13 and Figure 14). Similar to the inset weights, in those cases where a date may be suggested, they are generally found in burials broadly dated to the late 9th and/or first half of the 10th century (Aksdal 2017, 70-1). At the time of writing, there are no known examples of Anglo-Saxon swords and lead weights occurring in the same burials in Norway, but these two find categories sometimes overlap geographically (Figure 13). This is especially noticeable in south-eastern Norway, where a marked 
concentration of decorated lead weights and Anglo-Saxon swords are found in association with, or relatively close to, Kaupang. Indeed, the only Scandinavian examples of weights with coin insets come from Vik, Fjære approximately $150 \mathrm{~km}$ southwest of Kaupang (Figure 15). These came from a burial discovered in 1876 and both specimens comprise Anglo-Saxon stycas of Eanred, King of Northumbria (Williams 1999, 24). With regard to the wider Insular distribution, it is notable that only one coin weight is known from Ireland (set with a coin of Alfred of Wessex; Bourke 2010, 26 , 33, 74-5, no. 423, provenance uncertain), while at least 26 examples come from England (see Table 2).

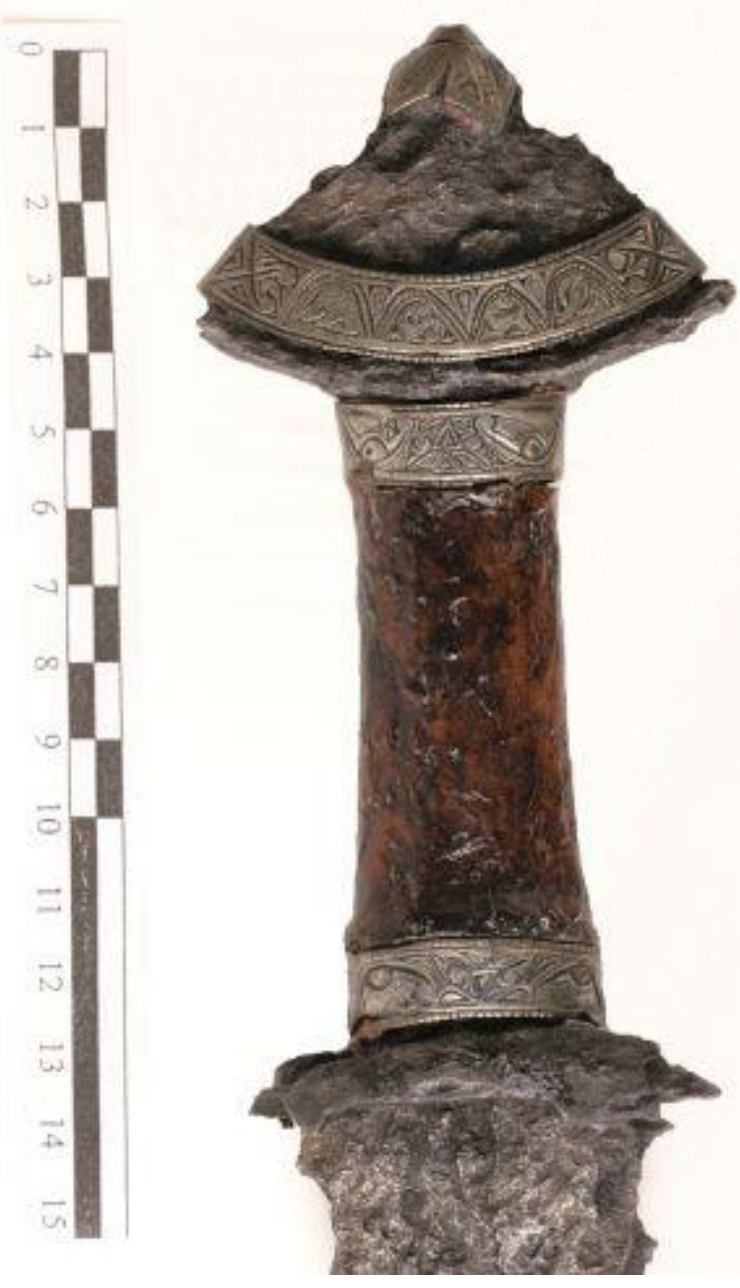

Figure 14: Anglo-Saxon sword from Hoven, Sunndal: one of 26 examples known from Norway. (Photo by Ole Bjørn Pedersen)

In addition to the archaeological material, several accounts in the early 13th-century Norse-Icelandic Kings sagas (Heimskringla) mention links between the early Norwegian kings and England in the late 9th and 10th centuries. Most famously, King Harald Fairhair is said to have sent his son Haakon the Good (reigned c. AD 933-60), to be fostered at the court of King Athelstan in England, where he was baptised. After the death of his father, Haakon returned to Norway to reclaim the throne from his halfbrother Erik Bloodaxe, who, according to the late 12th-century Ágrip, fled to England where he was granted the earldom of Northumbria (Downham 2004, 56-7). However, the historical value of these late sources is heavily debated (see e.g. Downham 2004 for a critical review of the sources which link Erik Bloodaxe to Northumbria). 


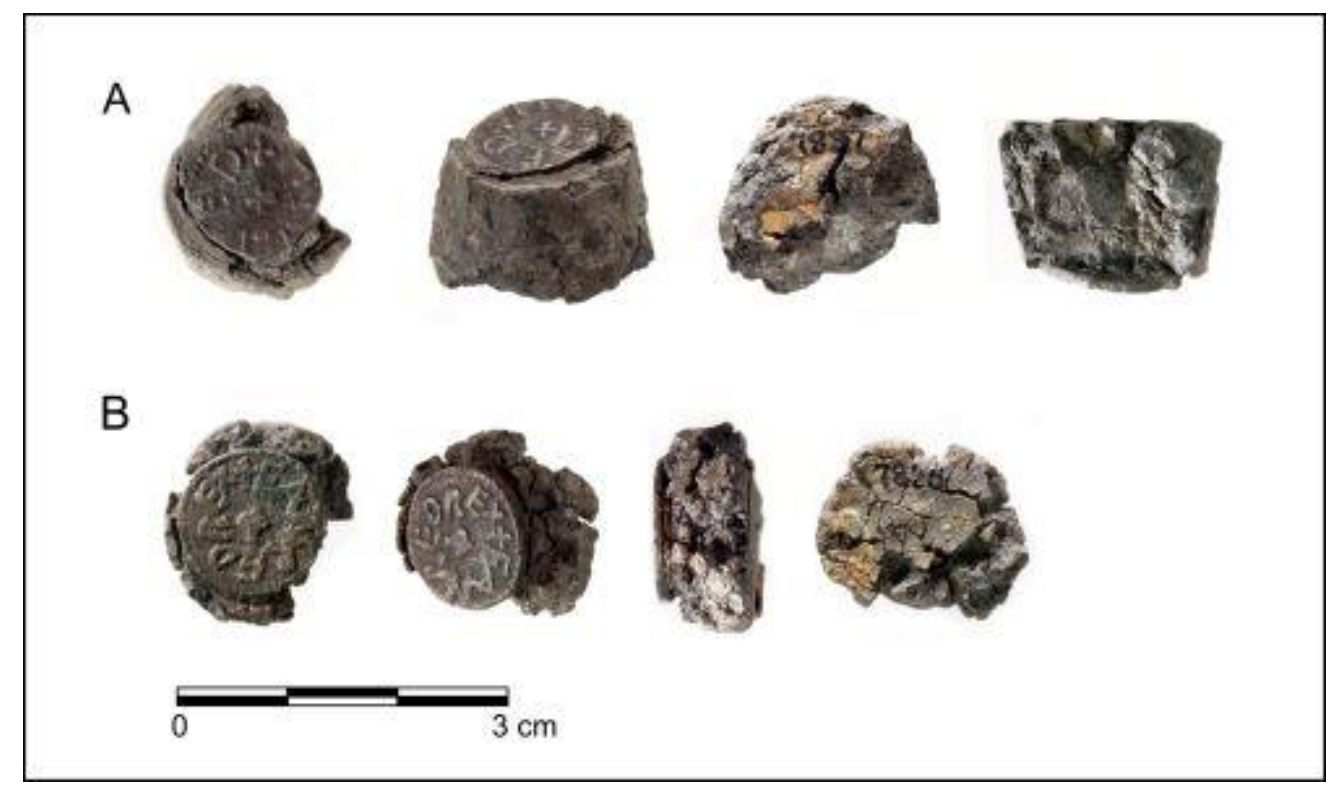

Figure 15: Coin inset weights from a male burial at Vik, Fjære which are the only examples of this type recovered from Norway. (Photos by Lill-Ann Chepstow-Lusty, $\mathrm{KHM})$

Nevertheless, news about the opportunities arising in England from the late 9th century onward may have travelled quickly to western Scandinavia, encouraging individuals and families to try their luck across the North Sea. When lead weights and Anglo-Saxon swords first arrive in Norway, it is clear that both the direct route from the west coast of Norway to northern Britain and Ireland and the longer continental course leading to England were well known. While both options may have brought the imports to Norway, it is noticeable that inset weights are found along the route taken by the Norse traveller Othere, who visited the court of King Alfred in the late 9th century (Englert 2007). This includes the newly discovered finds from Hedeby and the assemblage from Kaupang. Indeed, while inset weights are known as far north as Sandtorg, Harstad (no. 1 on fig.1), there is a marked concentration of such weights and Anglo-Saxon swords around Kaupang in the Viken area of south-eastern Norway (Figure 13), which was probably under Danish control until AD 900 at least (Skre 2007, 461-9). This could suggest that those who lived here were particularly drawn into Viking affairs in England in the late 9th and early 10th century. While some settled permanently overseas, others decided to return to their Scandinavian homelands, taking their weighing equipment with them.

When inset lead weights were brought to new Norse settings, further dimensions were added to their biographies. Their audience also changed, many of whom had probably never seen Britain or Ireland themselves. In Scandinavia, the insets may have served not only to customise an individual's weights, but also as an efficient means of demonstrating experience of the Insular world and an ability to enter into exchange relations with people beyond their country of origin (Baastrup 2013a, 14-15). This experience may have contributed to an elevated status for these individuals and their families when returning to their local communities. In Scandinavia, the relatively rarity of inset weights certainly indicates a different status for these objects from that in Britain and Ireland (Hall et al. 2020, 23). This is further emphasised by the fact that most of the examples seen in Scandanavia appear to have been especially selected for their distinctive and attractive motifs; weights with plain insets were only rarely taken to the Viking homelands. 
Regarding the wider utilisation of Insular metalwork, decorated lead weights and 'hackbronze' are phenomena which appear in the Viking milieu in the second half of the 9th and early 10th century, when mounts and other Insular dress ornaments largely, but not exclusively, disappear from burials in Norway. Furthermore, metalwork for scrap or bullion is mostly recovered from Britain and Ireland where, in contrast to the dress ornaments, it appears to have been 'commodified': it was traded and used free of previous biographical associations to particular events or people (Kopytoff 1986). This happened at a time when there was a sharp decline in the use of modified Insular imports worn on Norse female dress, thus reflecting a significant change in how Insular metalwork was used and perceived after three or four generations of overseas contact (Aannestad 2018, 12-13). The decline in the use of Insular metalwork as adornment forms part of a general trend in the late 9th and 10th century when altered imports in Norway 'are gradually replaced by foreign dress accessories used in keeping with European fashion' (Aannestad 2018, 13), to communicate conformity with neighbouring areas as Scandinavia became further integrated into international networks. Although foreign dress accessories continued to be an important means of displaying international contacts and affiliation, this was now mainly done with articles used as intended, such as beads, belt fittings, brooches and chains of copper alloy and silver (Aannestad 2018 , 12-13).

\section{Conclusions}

By considering the wider itineraries of inset lead weights, this article has suggested that some of the Norwegian finds demonstrate involvement with Viking milieus not only in Ireland, but also the Danelaw area. Together with Anglo-Saxon swords, inset lead weights may serve as material indicators of the evolving character of Insular contact in the late 9th and early 10th century which drew part of the Norse population into Viking affairs in England. While Insular metalwork continued to serve a display purpose for Scandinavians on both sides of the North Sea, by this time it was used mainly to decorate lead weights rather than the wives of returning Vikings. However, despite these changes in use, what appears to remain unchanged for these items is their importance as a demonstration of a distinctive materiality, with a strong association to the Insular world.

\section{Acknowledgements}

I am most grateful to the two anonymous referees for their constructive and useful feedback, and to Unn Pedersen, Griffin Murray, Martin Callanan and Randi Bjørshol Wærdahl for their valuable help in commenting on the original draft of the article. I would also like to thank Philip Wood for help with illustrations, Volker Hilberg for providing information and pictures of the new finds from Hedeby, and Gail Drinkall for language editing. This publication is Open Access and made possible by the generous support of the Norwegian University of Science and Technology Publication Fund. The article also received funding for language editing from the Norwegian Archaeological Society.

\section{Data and catalogue gallery}

https://intarch.ac.uk/journal/issue56/10/data.html 


\section{Bibliography}

Aannestad, H.L. 2015 Transformasjoner. Omforming og bruk av importerte gjenstander i vikingtid, unpublished $\mathrm{PhD}$ thesis: Oslo University.

Aannestad, H.L. 2018 'The Allure of the Foreign. The Social and Cultural Dimension of Imports in Scandinavia in the Viking Age', Viking and Medieval Scandinavia 14, 119. https://doi.org/10.1484/J.VMS.5.116387

Aksdal, J. 2017 'Dei anglosaksiske sverda. L-typesverd i England og

Skandinavia', Viking LXXX, 59-88. https://doi.org/10.5617/viking.5474

Androshchuk, F. 2014 Viking Swords: Swords and Social Aspects of Weaponry in Viking Age Societies, Statens Historiska Museum Studies 23, Stockholm: Statens Historiska Museum.

Baastrup, M.P. 2013a 'Irske lodder', Skalk 2014(4), 12-15.

Baastrup, M.P. 2013b 'Continental and Insular Imports in Viking Age Denmark: Distribution and Circulation', Zeitschrift fur Archaologie Mittelalters 41, 85-208.

Blindheim, M. 1984 'A house-shaped Irish-Scots reliquary in Bologna, and its place among the other reliquaries', Acta Archaeologica 55, 1-53.

Bourke, C. 2010 'Antiquities from the River Blackwater IV, early medieval non-ferrous metalwork', Ulster Journal of Archaeology 69, 24-133.

Downham, C. 2004 'Eric Bloodaxe - axed? The mystery of the last Scandinavian king of York', Medieval Scandinavia 14, 51-77.

Downham, C. 2007 Viking Kings of Britain and Ireland. The Dynasty of Ívarr to A.D. 1014, Edinburgh: Dunedin Academic Press Ltd.

Englert, A. 2007 'Ohthere's voyages seen from a nautical angle' in J. Bately and A. Englert (eds) Ohthere's Voyages. A late 9th-century Account of Voyages Along the Coasts of Norway and Denmark and its Cultural Context, Roskilde: The Viking Ship Museum. 117-29.

Glørstad, Z.T. 2012 'Sign of the Times? The Transfer and Transformation of Penannular Brooches in Viking-Age Norway', Norwegian Archaeological Review 45, 3051. https://doi.org/10.1080/00293652.2012.670379

Glørstad, Z.T. 2014 'Homeland - Strange Land - New Land. Material and Theoretical Aspects of Defining Norse Identity in the Viking Age' in J. Sigurdsson and T. Bolton (eds) Celtic-Norse Relationships in the Irish Sea in the Middle Ages 800-1200, Leiden and Boston: Brill Academic Publishers. 15170. https://doi.org/10.1163/9789004255128 010 
Graham-Campbell, J. 1980 Viking Artefacts: a Select Catalogue, London: The British Museum.

Graham-Campbell, J. 1986 'A late Celtic enamelled mount from Galson, Isles of Lewis', Proceedings of the Society of Antiquaries of Scotland 116, 281-4.

Graham-Campbell, J. and Batey, C.E. 1998 Vikings in Scotland: an archaeological survey, Edinburgh: Edinburgh University Press.

Hadley, D. 2012 'The creation of the Danelaw' in S. Brink (ed) The Viking World, London: Routledge. 375-9.

Hadley, D. and Richards, J.D. 2016 'The Winter Camp of the Viking Great Army, AD 872-73, Torksey, Lincolnshire', The Antiquaries Journal 96, 23-

67. https://doi.org/10.1017/S0003581516000718

Hadley, D. and Richards, J.D. 2018 'In search of the Viking Great Army: Beyond the Winter Camps', Medieval Settlement Research 33, 1-

17. https://doi.org/10.5284/1017430

Hall, R., Williams, G., Ager, B. and Rogers, N. 2020 'A Riverine Site Near York: A Possible Viking Camp?' in G. Williams (ed) A Riverine Site Near York: A Possible Viking Camp?, London: The British Museum. 3-102.

Harrison, S. 2014 'Historical background' in I. Russell and M.F. Hurley (eds) Woodstown. A Viking-Age settlement in Co. Waterford, Dublin: Four Courts Press. 10-20.

Harrison, S.H. and Ó Floinn, R. 2014 Viking Graves and Grave-Goods in Ireland, Dublin: National Museum of Ireland.

Heen-Pettersen, A.M. 2018 'Objects from a distant place: transformation and use of Insular mounts from Viking-Age burials in Trøndelag central Norway', Anglo-Saxon Studies in Archaeology and History 21: 60-75.

Heen-Pettersen, A.M. 2020 'Insular finds from Viking-Age Norway: Updating the Corpus' in S. Sindbæk and A. Pedersen (eds) Viking Encounters: Proceedings of the 18th Viking Congress, Aarhus: Aarhus Universitetsforlag. 435-48.

Jondell, E. 1974 Vikingetidens Balansåger i Norge, unpublished MA thesis: Uppsala University.

Kelly, E.P. 2007 'Artefact analysis' in A. O'Sullivan, R. Sands and E.P. Kelly (eds) Coolure Demesne Crannog, Lough Derravaragh: an introduction to its archaeology and landscape, Bray: Wordwell. 21-37.

Kershaw, J. 2013 Viking Identities. Scandinavian Jewellery in England, Oxford: Oxford University Press. https://doi.org/10.1093/acprof:oso/9780199639526.001.0001

Kershaw, J. 2016 'Scandinavian-style metalwork from Southern England: New Light on the 'First Viking Age' in Wessex' in R. Lavelle and S. Roffey (eds) Danes in Wessex. The 
Scandinavian Impact on Southern England, c. 800-c.1100, Oxford: Oxbow Books. 87108. https://doi.org/10.2307/j.ctvh1dprb.13

Kershaw, J. 2020 'Metals and Excange in Viking-Age Yorkshire: The Contribution of Single Finds' in G. Williams (ed) A Riverine Site near York: A Possible Viking Camp?, London: The British Museum. 3-102.

Kopytoff, I. 1986 'The cultural biography of things: commoditization as process' in A Appadurai (ed) The Social Life of Things: Commodities in Cultural Perspective, Cambridge: Cambridge University Press. 64-

91. https://doi.org/10.1017/CBO9780511819582.004

Kruse, S.E. 1992 'Late Saxon balances and weights from England', Medieval Archaeology 36, 67-95. https://doi.org/10.1080/00766097.1992.11735549

Laing, L. 1993 A Catalogue of Celtic Ornamental Metalwork in the British Isles, c AD 400-1200, BAR British Series 229, Oxford: Hadrian Books.

Marstrander, S. 1963 'Et nytt vikingtidsfunn fra Romsdal med vesteuropeiske importsaker', Viking XXVI, 123-56.

Mikkelsen, E. 2019 Looting or Missioning. Insular and continental sacred objects in Viking Age contexts in Norway, Oxford: Oxbow

Books. https://doi.org/10.2307/j.ctvpmw4np

Noon, S. 2014 'LANCUM-107126: An Early Medieval Weight', Portable Antiquities Scheme [website] https://finds.org.uk/database/artefacts/record/id/599470 (Accessed: 25 May 2021)

Ní Cheallacháin, M. 2019 'Preliminary results from excavations at Craddockstown North 1-5, Co. Kildare, Institute of Archaeologists in Ireland Newsletter 19(2), 36-7.

Ó Floinn, R. 2014 'Cast and gilt copper alloy' in I. Russell and M.F. Hurley (eds) Woodstown. A Viking-Age settlement in Co. Waterford, Dublin: Four Courts Press. 172-93.

Pedersen, U. and Pilø, L. 2007 'The Settlement: Artefacts and Site Periods', in D. Skre (ed) Kaupang in Skiringssal, Aarhus: Aarhus Academic Press. 179-90.

Pedersen, U. and Rødsrud, C.L. 2013 'Nye vektlodd fra Vestfold', Nicolay 119, 53-9.

Pedersen, U. 2001 'Vektlodd - sikre vitnesbyrd om handelsvirksomhet?', Primitive Tider 4, 19-36.

Pedersen, U. 2008 'Weights and balances' in D. Skre (ed) Means of Exchange. Dealing with Silver in the Viking Age, Aarhus: Aarhus University Press. 119-95.

Pedersen, U. 2016 Into the Melting Pot. Non-ferrous Metalworkers in Viking-period Kaupang, Kaupang Excavation Project Publication Series 4, Denmark: Narayana Press. 
Pestell, T. 2013 'Imports or immigrants? Reassessing Scandinavian metalwork in late Anglo-Saxon East Anglia' in D. Bates and D. Liddiard (eds) East Anglia and its North Sea World in the Middle Ages, Woodbridge: Boydell. 230-55.

Petersen, J. 1940 'British Antiquities of the Viking Period found in Norway', Viking Antiquities in Great Britain and Ireland 5, Oslo: Aschehough \& Co.

Pilø, L. and Skre, D. 2011 'Introduction to the site' in D. Skre (ed) Things from the Town. Artefacts and Inhabitants in Viking-age Kaupang, Kaupang Excavation Project Publication Series, Volume 3, Norske Oldfunn XXIV, Oslo: Aarhus University Press \& the Kaupang Excavation Project. 17-26. https://www.duo.uio.no/handle/10852/44036

Redknap, M. 2007 'Crossing boundaries - stylistic diversity and external contacts in early medieval Wales and the March: reflections on metalwork and sculpture' in P. SimsWilliams and G. Aled Williams (eds) Crossing Boundaries/Croesi Ffiniau, Proceedings of the XIIth International Congress of Celtic Studies 24-30 August 2003, University of Wales, Aberystwyth, Aberystwyth: Cambridge Medieval Celtic Studies 53/54. 23-86.

Richards, J.D. and Haldenby, D. 2018 'The Scale and Impact of Viking Settlement in Northumbria', Medieval Archaeology 62(2), 322-

50. https://doi.org/10.1080/00766097.2018.1535382

Ryan, M. 1989 'Church metalwork in the eighth and ninth centuries' in S. Youngs (ed) The Work of Angels. Masterpieces of Celtic Metalwork, 6th-9th centuries AD, London: The British Museum. 125-69.

Sheehan, J. 2013 'Viking raiding, gift-exchange and insular metalwork in Norway' in A. Reynolds and L. Webster (eds) Early medieval art and archaeology in the Northern World. Studies in honour of James Graham-Campbell, Leiden: Brill. 809-23.

Sindbæk, S.M. 2011 'Silver economies and social ties. Long-distance interaction, longterm investments - and why the Viking Age happened' in J. Graham-Campbell, S.M. Sindbæk and G. Williams (eds) Silver Economies, Monetisation and Society in Scandinavia AD 800-1100, Aarhus: Aarhus University Press. 41-66.

Skre, D. 2007 'Towns and Marekts, Kings and Central Places in South-western Scandinavia C. AD 800-950' in D. Skre (ed) Kaupang in Skiringssal, Aarhus: Aarhus Academic Press. 445-469.

Sørheim, H. 2011 'Three prominent Norwegian ladies with British connections', Acta Archaeologica 82, 17-54. https://doi.org/10.1111/j.1600-0390.2011.00377.x

Wallace, P.F. 2014 'Weights' in I. Russell and M.F. Hurley (eds) Woodstown. A VikingAge settlement in Co. Waterford, Dublin: Four Courts Press. 222-55.

Wallace, P. F. 2016 Viking Dublin: The Wood Quay Excavations, Kildare: Irish Academic Press.

Wamers, E. 1985 Insularer Metallschmuck in wikingerzeitlichen Gräbern Nordeuropas. Untersuchungen zur skandinavischen Westexpansion, Neumunster: Karl Wachholtz Verlag. 
Wamers, E. 2011 'Continental and Insular metalwork' in D. Skre (ed) Things from the Town. Artefacts and Inhabitants in Viking-age Kaupang, Kaupang Excavation Project Publication Series, Volume 3, Norske Oldfunn XXIV, Oslo: Aarhus University Press \& the Kaupang Excavation Project. 65-98. https://www.duo.uio.no/handle/10852/44036

Williams, G. 1999 'Anglo-Saxon and Viking Coin Weights', British Numismatic Journal 69, 19-36.

Williams, G. 2015 'Viking Camps and the means of exchange in Britain and Ireland in the ninth century' in H.B. Clarke and R. Johnson (eds) The Vikings in Ireland and beyond: before and after the Battle of Clontarf, Dublin: Four Courts Press. 93-116.

Youngs, S. 2001 'From Ireland Coming: Fine Irish Metalwork from the Medway, Kent, England' in C. Hourihane (ed) From Ireland Coming. Irish Art from the Early Christian to the late Gothic period and its European Context, Princeton, New Jersey: Princeton University Press. 249-60.

Youngs, S. 2017 'From island to island and beyond: workshop practices and the cultural roots of fine metalwork in the eight century' in C. Newman, M. Mannion and F. Gavin (eds) Island in a Global Context: Proceedings of the seventh international conference on Insular art, held at the National University of Ireland, Galway, 16-20 July 2014, Dublin: Four Courts Press. 266-74. 